\title{
Genetic parameters of forage dry matter intake and milk produced from forage in Swedish Red and Holstein dairy cows
}

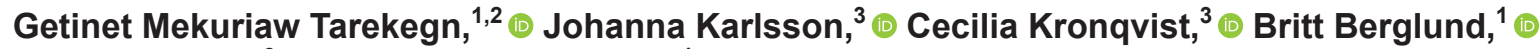 \\ Kjell Holtenius, ${ }^{3}{ }^{\oplus}$ and Erling Strandberg ${ }^{1 *}$ () \\ ${ }^{1}$ Department of Animal Breeding and Genetics, Swedish University of Agricultural Sciences, Uppsala 75007, Sweden \\ ${ }^{2}$ Department of Animal Production and Technology, Bahir Dar University, Bahir Dar, Ethiopia \\ ${ }^{3}$ Department of Animal Nutrition and Management, Swedish University of Agricultural Sciences, Uppsala 75007 Sweden
}

\begin{abstract}
High-yielding dairy cows are often fed high proportions of cereal grain and pulses. For several reasons, it would be desirable to replace these feed sources with forage, which is not suitable for human consumption. Feeding large amounts of forage to dairy cows could also make dairy production more publicly acceptable in the future. In this study, we estimated genetic parameters for total dry matter intake (DMI), DMI from forage $\left(\mathrm{DMI}_{\mathrm{For}}\right)$, energy-corrected milk (ECM), and ECM produced from forage $\left(\mathrm{ECM}_{\mathrm{For}}\right)$. A total of 1,177 lactations from 575 cows of Swedish Red (SR) and Holstein (HOL) dairy breeds were included in the study. Mixed linear animal random regression models were used, with fixed effect of calving season and lactation week nested within parity 1 and $2+$, fixed effect of calving year, and random regression coefficients for breeding value (up to linear) and permanent environmental effect (up to quadratic) of the cow. Heritability for DMI and $\mathrm{DMI}_{\mathrm{For}}$ was generally higher for HOL than for SR in all-parity data and in later parities; however, the opposite was true for first parity. Heritability for DMI and $\mathrm{DMI}_{\text {For }}$ during the first 8 wk averaged 0.11 and 0.15 , respectively, in all-parity data for the 2 breeds. Corresponding values for $\mathrm{ECM}_{\mathrm{For}}$ and $\mathrm{ECM}$ were 0.21 and 0.29 , respectively. In first parity, values were $0.32,0.36,0.28$, and 0.51 , respectively. The genetic correlation between DMI and $\mathrm{DMI}_{\mathrm{For}}$ was high, above 0.83 , and fairly constant across the lactation. The genetic correlation between $\mathrm{ECM}_{\mathrm{For}}$ and $\mathrm{ECM}$ was close to unity in the later part of lactation for both breeds, but was around 0.8 in the early lactation for both breeds; it decreased for HOL to 0.54 in wk 17. The genetic correlations between DMI and $\mathrm{ECM}_{\text {For }}$ and between $\mathrm{DMI}_{\text {For }}$ and $\mathrm{ECM}_{\text {For }}$ were low
\end{abstract}

Received July 6, 2020.

Accepted November 17, 2020.

*Corresponding author: Erling.Strandberg@slu.se and negative for HOL (absolute value $\sim 0.2-0.3$ ), but changed for SR from weakly positive in early lactation to negative values and back to positive toward the end of lactation. For most traits, the correlation between wk 1 and wk 8 into the lactation was very high; the lowest value was for DMI in HOL at 0.81 . The genetic correlation between parities was rather high in the first part of the lactation. During the first $8 \mathrm{wk}$, the correlation was lower for HOL than for SR, except for ECM. We found that $\mathrm{DMI}_{\mathrm{For}}$ and $\mathrm{ECM}_{\mathrm{For}}$ showed reasonably large heritability, and future work should explore the possibility of genomic evaluations.

Key words: roughage, feed efficiency, heritability

\section{INTRODUCTION}

Productivity in dairy cows has increased because of continuous selection and application of various breeding techniques, improved feeding strategies, and enhanced healthcare (Arefaine and Bertilsson, 2015). High-yielding dairy cows are often fed high proportions of cereal grain and pulses that could be consumed directly by humans (FAO, 2014). Such diets also increase the risk of rumen acidosis and lower fat content in milk (Boddugari et al., 2001; Patel, 2012). Replacing cereal grain and pulses in the diet of dairy cows with forage not suitable for human consumption would increase net food production (Ertl et al., 2015, 2016; Karlsson et al., 2018). Forage cannot be consumed by humans, but high-quality forage has the potential to sustain high milk production in dairy cows (Randby et al., 2012; Karlsson et al., 2020). Inclusion of forage production in crop rotations contributes to several ecosystem services, such as improved soil quality, carbon sequestration, and control of pests and weeds (Weißhuhn et al., 2017). Feeding large amounts of good-quality forage to dairy cows has several advantages. These include a reduced amount of purchased concentrates (Patel, 2012), increased fat content of the milk, improved rumen function, lower veterinary costs, and increasing productive 
lifetime of the cow (Chase and Grant, 2013). Rising concern about the consequences of climate change may also drive forage production (e.g., in the Scandinavian region) because it has been identified as a mitigation option, but also as an adaptation to a longer growing season in a warmer future climate (EEA, 2021). Feeding large amounts of forage to dairy cows could also make dairy production more publicly acceptable in the future. However, before introducing this concept, we should breed cows that can meet their nutritional requirements for high milk production on diets high in forage and low in concentrates, which suggests selection for cows that can consume large amounts of forage and still maintain high production.

The cost of feed is considered the main determining factor in dairy production, as it is the largest (up to $60 \%$ ) contributor to operating costs (European Commission, 2013). Due to limited access to feed intake data for large populations of animals, inclusion of feed intake measures in the breeding goal and selection criteria has remained poorly addressed in most dairy cattle breeding programs (Berry et al., 2014). In Australia (Pryce et al., 2018) and the Netherlands (de Jong et al., 2016), feed efficiency is included in national selection indices in dairy cattle breeding. The possibility of including feed efficiency in Nordic dairy cattle breeding was studied by Li (2018). In August 2019, a trait called "Saved Feed" was introduced into the Nordic genetic evaluations, thus far based only on predicted maintenance needs (NAV, 2020).

Data on feed intake traits, especially for non-Holstein dairy cows, are not as readily available and accessible as data on production traits. Several studies have been carried out on feed efficiency-related traits where genetic evaluation of those traits has been performed with the intention of including feed efficiency in breeding goals (Hüttmann et al., 2009; Buttchereit et al., 2011; Liinamo et al., 2012; Berry et al., 2014; Tetens et al., 2014; Li et al., 2016, 2017, 2018; Manzanilla Pech et al., 2016). These studies revealed (1) heterogeneity of genetic parameter estimates of feed intake traits across parities and lactation stages and (2) variability of genetic correlations between feed intake and production or functional traits. Studies on Holstein (HOL) cows indicate a wide range of heritability estimates, and variation in estimates has also been reported between parities and between periods within a lactation (Manzanilla Pech et al., 2014b; Tetens et al., 2014; Li et al., 2016). Very few studies of genetic evaluation for feed intake have been performed for cattle breeds other than HOL. Liinamo et al. (2012) evaluated genetic parameters for DMI for the Nordic Red dairy breed and Li et al. (2016) estimated heritability for the Nordic Red and Jersey breeds, in addition to the HOL breed. Moreover, most studies suffer from small data sizes due to the cost and difficulty of measuring feed intake. This reduces the accuracy of selection and possibility of selecting breeding animals (Manzanilla Pech et al., 2014a).

However, the studies mentioned examined total DMI, but there are no studies specifically targeting forage intake. Furthermore, for reasons listed above, there is a need for cows that can produce a large amount of milk on forage diets, without large-scale supplementation with grains and concentrates. The main aim of the present study was to estimate genetic parameters of forage DMI and of a new trait, ECM produced from forage, in Swedish Red (SR) and HOL cows.

\section{MATERIALS AND METHODS}

\section{Animals and Housing}

A total of 575 Swedish dairy cows (748 lactations of $356 \mathrm{SR}$ and 429 lactations of 219 HOL cows) at Swedish Livestock Research Centre, Swedish University of Agricultural Sciences (SLU), Uppsala, Sweden, were used in the study. The animals were housed in accordance with the laws and regulations for experiments performed with live animals in Sweden. The data were collected between August 2013 and October 2018.

The cows were housed in a loose housing barn with rubber mat and sawdust-bedded cubicles. There was at least 1 cubicle per cow to ensure all cows had the possibility to rest. The cows were milked in a singlestation automated milking system (VMS, DeLaval International AB, Tumba, Sweden) with the FeedFirst cow traffic system. A maximum of 60 cows were housed in the same area at a time and milked by 1 milking station.

\section{Diets and Feeding}

The cows were fed forage and concentrates separately. All cows had free access to grass-clover silage stored in bunker silos, which was fed in feed troughs placed on weighing cells. There were 20 troughs available, and each cow was identified with a radio frequency identification transponder when approaching the trough. The feed troughs registered the amount of feed leaving the feed trough during the time a cow had her head inside the trough. Forage intake per cow and visit was summed up to daily individual forage intake. The troughs were refilled approximately 5 times per day to ensure that the cows had free access to forage. Concentrate ration per cow was calculated based on milk yield or as fixed ration based on lactation stage. Concentrates were fed in feeding stations, 4 serving a group of approximately 60 cows. 


\section{Measurements and Sample Collection}

Individual daily forage intake was recorded automatically (CRFI, BioControl Norway As, Rakkestad, Norway), as was daily concentrate intake (DelPro, DeLaval International AB, Tumba, Sweden). The equipment used for forage intake recording was calibrated weekly, and that used for concentrate was calibrated monthly. Silage was sampled 5 times per week and pooled into 3 -wk periods for analysis of chemical composition. Silage samples were collected in plastic bags and stored at $-20^{\circ} \mathrm{C}$ until analysis.

All forage analyses were performed by the laboratory at the Department of Animal Nutrition and Management, Swedish University of Agricultural Science, Uppsala, Sweden. The DM content of the silage was determined by first drying at $60^{\circ} \mathrm{C}$ overnight, grinding, and then drying again at $60^{\circ} \mathrm{C}$ overnight, according to Åkerlind et al. (2011). Metabolizable energy content in the silage was estimated by the $96-\mathrm{h}$ in vitro digestible organic matter (IVOMD) method according to Lindgren (1983) as follows: $\mathrm{ME}[\mathrm{MJ} / \mathrm{kg}$ of $\mathrm{OM}]=0.160$ $\times$ IVOMD [\%] - 1.91. Metabolizable energy was then converted to megajoule per kilogram of DM based on ash content determined by ignition at $550^{\circ} \mathrm{C}$ for $3 \mathrm{~h}$. Silage was analyzed for CP in an automated Kjeldahl procedure (Foss, Hillerød, Denmark). On average, according to our data, the silage fed in the study contained 11.4 MJ of ME and $161 \mathrm{~g}$ of CP per kilogram of DM.

The ME content in concentrate was calculated using tabulated values according to the Swedish Board of Agriculture (SJVFS, 2011) or provided by the concentrate manufacturer. The DMI and ME intake were calculated daily for forage, concentrate, and in total.

Milk yield was recorded at each milking, and milk sampling was generally carried out every second week. The equipment used for measuring milk yield and for milk sampling has been certified by the International Committee for Animal Recording (ICAR, Rome, Italy). Milk samples were preserved with bronopol, stored at $8^{\circ} \mathrm{C}$, and analyzed within $3 \mathrm{~d}$. Milk samples were analyzed for composition of fat, protein, and lactose by infrared Fourier transform spectroscopy. The ECM per day was calculated according to Sjaunja et al. (1990) as follows:

$$
\begin{aligned}
\mathrm{ECM}= & \text { milk yield } \times(383 \times \text { Fat } \%+242 \times \text { Protein } \% \\
& +157 \times \text { Lactose } \%+20.7) / 3,140
\end{aligned}
$$

where Fat\%, Protein\%, and Lactose\% are the percentage of fat, protein, and lactose concentration, respectively, in the milk. Milk yield was measured daily, but fat, protein, and lactose concentration data were only available twice a month, or occasionally less frequently. Therefore, Proc Expand in SAS (2012) was used for linear interpolation between days with known concentrations. For days that still lacked information, an average of the concentrations was calculated for every lactation month for each cow and used for calculation of ECM. If a lactation month lacked concentration information, the average concentration for that parity of the cow was used instead.

\section{Data Editing}

Observations were excluded from the analysis if milk yield was less than $5 \mathrm{~kg} / \mathrm{d}$ or greater than $80 \mathrm{~kg} / \mathrm{d}$, DMI was greater than $40 \mathrm{~kg} / \mathrm{d}$, forage DMI was less than $10 \mathrm{~kg} / \mathrm{d}$, or fat percentage was greater than $6.5 \%$ or less than $1 \%$. Data from periods when cows were out on pasture were excluded (generally mid-May to midAugust). Weekly averages of daily observations of milk and feed intake were used for the final analysis.

\section{Traits and Statistical Analysis}

The main focus of this study was on forage intake, and thus forage DMI ( $\mathbf{D M I} \mathbf{F o r}_{\mathrm{Fo}}$ ) was the main trait. However, to compare the results with previous studies, total DMI and ECM were also studied. Because individual forage intake is normally difficult to record, but concentrate intake information is potentially available in commercial herds with separate forage and concentrate feeding, a trait called "ECM produced from forage" $\left(\mathbf{E C M}_{\text {For }}\right)$ was defined to find cows that can produce a large amount of milk on forage. The $\mathrm{ECM}_{\mathrm{For}}$ was calculated as follows:

$$
\begin{gathered}
\mathrm{ECM}_{\mathrm{For}}= \\
\mathrm{ECM}-\left[\left(\mathrm{MEI}_{\mathrm{Conc}}-\text { Maintenance need }\right) / 5.0\right],
\end{gathered}
$$

where the expected ECM produced from the energy intake from concentrate $\left(\mathrm{MEI}_{\text {Conc }}\right)$ is deducted from the actual ECM after first covering the maintenance needs from concentrate. We assumed that $1 \mathrm{~kg}$ of ECM required $5 \mathrm{MJ}$ of ME. The maintenance need was calculated as $0.507 \times \mathrm{BW}^{0.75}$, where $\mathrm{BW}^{0.75}$ is the metabolic body weight. The ME requirements for maintenance and milk were based on Eriksson et al. (1976). The remaining ECM was assumed to be produced from forage. It was not possible to calculate the maintenance need per individual in our data, owing to lack of frequent weight records; therefore, it was based on average weight of 560, 650 , and $680 \mathrm{~kg}$ in first, second, and later 
parities, using the available weight data. There was no weight difference between the breeds in our data.

Calculation of descriptive statistics and estimation of significance of fixed effects were carried out in SAS software version 9.4 (SAS, 2012) using Proc Mixed. For the latter, weekly averages over the whole lactation (wk 1-40) for all parities were analyzed in a model with a random cow effect, $\mathrm{pe}_{\mathrm{n}} \sim \operatorname{IND}\left(0, \sigma_{p e}^{2}\right)$, where IND is independently, normally distributed. Effect of breed, parity, calving season, calving year, and lactation stage were tested, including interactions with parity.

The heritability of DMI, DMI For $\mathrm{ECM}_{\text {For }}$, and ECM was estimated using the following mixed linear random regression animal model in the DMU package (Madsen and Jensen, 2013) as follows:

$$
\begin{aligned}
& y_{i j k l m}=\mu+C Y_{i}+S_{j}+L W_{k}+\sum_{n=0}^{1} a_{l n} d_{m}^{n} \\
& +\sum_{n=0}^{2} p e_{l n} d_{m}^{n}+e_{i j k l m},
\end{aligned}
$$

where $y_{i j k l m}$ is the weekly average of the analyzed trait; $\mu$ is the overall mean; $C Y_{i}$ is the fixed effect of $i$ th calving year $(i=2013, \ldots, 2018) ; S_{j}$ is the fixed effect of $j$ th calving season $(j=$ December-February, MarchMay, June-August, and September-November) nested within parity group 1 and $2+; L W_{k}$ is the fixed effect $k$ th of lactation week (wk 1-2, 3, 4, .., 24, 25-27, 28-30, 31-33, 34-36, 37-40 nested within parity group 1 and $2+) ; a_{l n}$ is the additive genetic random regression coefficient of cow $l$ of degree $n$, and $d_{m}^{n}$ is a linear function of day in milk $m$, going from -1 to 1 , raised to $n$, $\sim N D(\mathbf{0}, \mathbf{G} \otimes \mathbf{A})$, where $\mathbf{A}$ is the additive relationship matrix using pedigree information traced back 5 generations; $p e_{l n}$ is permanent environmental random regression coefficient of cow $l$ of degree $n, \sim N D\left(\mathbf{0}, \mathbf{P E} \sigma_{p e}^{2}\right)$;

and $e_{i j k l m}$ is the random residual $\sim N D\left(\mathbf{0}, \mathbf{I} \sigma_{e}^{2}\right)$. The variance-covariance structure for the additive and permanent environmental effects were as follows:

$$
\mathbf{G}=\left[\begin{array}{cc}
\sigma_{a 0}^{2} & \sigma_{a 01} \\
\operatorname{sym} . & \sigma_{a 1}^{2}
\end{array}\right]
$$

and

$$
\mathbf{P E}=\left[\begin{array}{ccc}
\sigma_{p e 0}^{2} & \sigma_{p e 01} & \sigma_{p e 02} \\
& \sigma_{p e 1}^{2} & \sigma_{p e 12} \\
s y m . & & \sigma_{p e 2}^{2}
\end{array}\right] .
$$

Additive genetic variance for a given day in milk $m$ was calculated as $\mathbf{x}^{\prime} \mathbf{G x}$, where $\mathbf{x}^{\prime}=\left[\begin{array}{ll}1 & d_{m}\end{array}\right]$, and permanent environmental variance was calculated as $\mathbf{x}^{\prime} \mathbf{P E x}$, where $\mathrm{x}^{\prime}=\left[\begin{array}{lll}1 & d_{m} & d_{m}{ }^{2}\end{array}\right]$. Heritability at a given day was estimated as $\hat{\sigma}_{a}^{2} /\left(\hat{\sigma}_{a}^{2}+\hat{\sigma}_{e}^{2}\right)$ and repeatability as $\left(\hat{\sigma}_{a}^{2}+\hat{\sigma}_{p e}^{2}\right) /\left(\hat{\sigma}_{a}^{2}+\hat{\sigma}_{p e}^{2}+\hat{\sigma}_{e}^{2}\right)$. Genetic correlations within lactation were estimated from the covariance $\mathbf{x}^{\prime} \mathbf{G x}$, where the 2 vectors refer to different days. The data set was also analyzed separately for first- and later-parity cows. A bivariate version of model [1] was used to estimate genetic correlations between traits based on allparity data and between the same trait in first parity and later parities, also including covariances between traits for all random effects in addition to the variances described above.

\section{RESULTS AND DISCUSSION}

\section{Descriptive Statistics and Fixed Effects}

Summary statistics for feed intake traits and $\mathrm{ECM}_{\mathrm{For}}$ are shown in Table 1, together with those for milk production traits. Our averages for total DMI were higher than those obtained for HOL $(19.4 \pm 3.2 \mathrm{~kg}$ of DM/d; mean $\pm \mathrm{SD})$, Nordic Red $(18.5 \pm 3.3 \mathrm{~kg}$ of $\mathrm{DM} / \mathrm{d})$, and Jersey $(15.8 \pm 2.9 \mathrm{~kg}$ of $\mathrm{DM} / \mathrm{d})$ first-parity cows in the Nordic countries presented by Li et al. (2018). They were also higher than those reported for Dutch herds (20.7 kg of DM/d), but similar to those reported for US herds $(24.1 \mathrm{~kg} / \mathrm{d}$; Manzanilla Pech et al., 2016). Berry et al. (2007) reported values for grass DMI corresponding to an average value of $16.5 \mathrm{~kg}$ of $\mathrm{DM} / \mathrm{d}$, which is higher than our values for $\mathrm{DMI}_{\mathrm{For}}$.

All fixed factors tested in the statistical model were highly significant $(P<0.0001)$. The estimates for breed, parity, and calving season are shown in Table 2. Holstein had a higher DMI and $\mathrm{DMI}_{\text {For }}$ than SR. Total DMI and $\mathrm{DMI}_{\mathrm{For}}$ were lower in first parity. Cows calving in late fall had the highest DMI and $\mathrm{DMI}_{\mathrm{For}}$, whereas those calving in spring had the highest EC$\mathrm{M}_{\mathrm{For}}$. Total DMI showed an increasing trend over the first 5 to 6 lactation weeks, whereas $\mathrm{DMI}_{\text {For }}$ showed a stable or slightly decreasing trend at the beginning of the lactation, coinciding with a large increase in concentrate intake in the first few weeks (not shown), and a slow increase after the fifth lactation week until mid lactation (Figure 1).

There are almost no previous studies separating forage DMI from total DMI, with most studies examining the latter trait. Berry et al. (2007) observed an increasing trend in grass DMI on pasture throughout the lactation in HOL cows, with the highest intake at about 
Table 1. Summary statistics [number of observations (n), mean \pm SD] and minimum and maximum of weekly records of total DMI, forage DMI (DMI For $)$, and ECM produced on forage $\left(\mathrm{ECM}_{\mathrm{For}}\right.$; all in $\left.\mathrm{kg} / \mathrm{d}\right)$, and daily records on milk yield $(\mathrm{kg} / \mathrm{d})$, fat percentage, and protein percentage, based on data for 1,177 lactations in 575 cows of the Swedish Red and Holstein breeds

\begin{tabular}{|c|c|c|c|c|c|c|}
\hline \multirow[b]{2}{*}{ Trait } & \multicolumn{3}{|c|}{ Swedish Red } & \multicolumn{3}{|c|}{ Holstein } \\
\hline & $\mathrm{n}$ & Mean \pm SD & $\operatorname{Min} / \max$ & $\mathrm{n}$ & Mean \pm SD & $\operatorname{Min} / \max$ \\
\hline Total DMI & 11,565 & $23.6 \pm 4.5$ & $10.4 / 38.4$ & 6,823 & $25.0 \pm 5.1$ & $10.6 / 39.6$ \\
\hline $\mathrm{DMI}_{\text {For }}$ & 11,565 & $13.4 \pm 4.0$ & $5.0 / 29.7$ & 6,823 & $14.6 \pm 4.4$ & $5.0 / 29.7$ \\
\hline $\mathrm{ECM}_{\text {For }}$ & 11,272 & $20.8 \pm 8.3$ & $-8.3 / 61.4$ & 6,658 & $21.5 \pm 8.5$ & $-10.7 / 58.3$ \\
\hline $\mathrm{ECM}$ & 11,272 & $34.9 \pm 7.7$ & $10.2 / 72.7$ & 6,658 & $36.0 \pm 8.2$ & $10.7 / 69.1$ \\
\hline Milk yield & 71,911 & $34.8 \pm 9.4$ & $10.0 / 78.5$ & 42,625 & $36.6 \pm 10.2$ & $10.0 / 79.9$ \\
\hline Fat $\%$ & 6,047 & $4.16 \pm 0.73$ & $2.00 / 6.45$ & 3,526 & $4.00 \pm 0.75$ & $2.00 / 6.50$ \\
\hline Protein \% & 6,206 & $3.46 \pm 0.31$ & $2.00 / 5.99$ & 3,619 & $3.37 \pm 0.31$ & $2.3 / 5.87$ \\
\hline
\end{tabular}

30 to 35 wk. The slight drop in $\mathrm{DMI}_{\mathrm{For}}$ that can be seen in Figure 1 could not have been detected in their study because their first lactation stage was d 8 to 50 (up to $7 \mathrm{wk}$ ), and the drop we observed occurred within that period. Previous studies have also reported an increase in total DMI in early lactation, followed by a stable or slightly declining trend in later lactation (Koenen and Veerkamp, 1998; Vallimont et al., 2010; Li et al., 2016).

In our study, SR and HOL cows consumed $56.8 \%$ and $58.4 \%$, respectively, of their total DMI from forage. These proportions decreased in early lactation to the lowest value in wk $5(50 \%)$ and then increased to values slightly above $60 \%$ at the end of lactation (results not shown). On average, $\mathrm{ECM}_{\text {For }}$ was higher for HOL cows than for SR (Table 2). The $\mathrm{ECM}_{\mathrm{For}}$ values showed a rapidly decreasing trend in the first 5 wk of lactation for both breeds and both parity groups (Figure 2). For first-parity cows, $\mathrm{ECM}_{\mathrm{For}}$ then increased by about $5 \mathrm{~kg}$ until the end of the lactation.

\section{Estimates of Heritabilities and Correlations}

For the genetic model, which was applied within breed, we found significant $(P<0.05)$ interactions between parity on one hand and calving year, calving season, and lactation stage on the other. The latter is also indicated in Figures 1 and 2. However, upon inspection of the estimates, the general trend over calving years was similar between first and later parities. Therefore, we included only calving season and lactation stage (week) as nested within first and later parities in the genetic model. In a preliminary analysis, we also attempted to have a quadratic term for the additive genetic component; however, these models did not converge.

Owing to the small data set, the standard errors of both heritability and especially genetic correlation estimates were large. This should be kept in mind when interpreting the results. Statements about differences

Table 2. The $\mathrm{LSM}^{1} \pm \mathrm{SE}$ of DMI, $\mathrm{DMI}_{\mathrm{For}}, \mathrm{ECM}_{\mathrm{For}}$, and ECM for Swedish Red and Holstein cows

\begin{tabular}{|c|c|c|c|c|}
\hline \multirow[b]{2}{*}{ Fixed effect } & \multicolumn{4}{|c|}{ Trait $^{2}$} \\
\hline & DMI & $\mathrm{DMI}_{\mathrm{For}}$ & $\mathrm{ECM}_{\mathrm{For}}$ & ECM \\
\hline \multicolumn{5}{|l|}{ Breed } \\
\hline Swedish Red & $23.4 \pm 0.12^{\mathrm{a}}$ & $12.8 \pm 0.12^{\mathrm{a}}$ & $19.0 \pm 0.36^{\mathrm{a}}$ & $33.8 \pm 0.24^{\mathrm{a}}$ \\
\hline Holstein & $25.0 \pm 0.15^{\mathrm{b}}$ & $14.2 \pm 0.12^{\mathrm{b}}$ & $20.7 \pm 0.28^{b}$ & $36.1 \pm 0.31^{b}$ \\
\hline \multicolumn{5}{|l|}{ Parity } \\
\hline 1 & $22.0 \pm 0.10^{\mathrm{a}}$ & $12.7 \pm 0.10^{\mathrm{a}}$ & $17.2 \pm 0.23^{\mathrm{a}}$ & $29.7 \pm 0.20^{\mathrm{a}}$ \\
\hline 2 & $24.9 \pm 0.11^{b}$ & $13.7 \pm 0.11^{b}$ & $20.5 \pm 0.25^{\mathrm{b}}$ & $36.7 \pm 0.21^{\mathrm{b}}$ \\
\hline 3 & $25.7 \pm 0.13^{\mathrm{c}}$ & $14.1 \pm 0.14^{\mathrm{c}}$ & $21.8 \pm 0.29^{\mathrm{c}}$ & $38.5 \pm 0.24^{\mathrm{c}}$ \\
\hline \multicolumn{5}{|l|}{ Calving season } \\
\hline Dec-Feb & $23.9 \pm 0.12^{\mathrm{a}}$ & $12.7 \pm 0.12^{\mathrm{a}}$ & $18.7 \pm 0.26^{\mathrm{a}}$ & $35.3 \pm 0.22^{\mathrm{a}}$ \\
\hline Mar-May & $23.3 \pm 0.14^{\mathrm{b}}$ & $13.2 \pm 0.14^{b}$ & $21.3 \pm 0.29^{b}$ & $34.9 \pm 0.24^{\mathrm{al}}$ \\
\hline Jun-Aug & $24.6 \pm 0.13^{\mathrm{c}}$ & $13.9 \pm 0.13^{\mathrm{c}}$ & $19.6 \pm 0.27^{\mathrm{c}}$ & $34.8 \pm 0.23^{\mathrm{b}}$ \\
\hline Sep-Nov & $25.0 \pm 0.12^{\mathrm{d}}$ & $14.2 \pm 0.12^{\mathrm{d}}$ & $19.7 \pm 0.26^{\mathrm{c}}$ & $34.8 \pm 0.22^{\mathrm{b}}$ \\
\hline
\end{tabular}

${ }^{\mathrm{a}-\mathrm{d}}$ Estimates with different superscripts are significantly different $(P<0.05)$.

${ }^{1}$ LSM are from a model with an overall effect of lactation week rather than the nested effect; otherwise LSM were nonestimable.

${ }^{2} \mathrm{DMI}_{\mathrm{For}}=\mathrm{DMI}$ of forage; $\mathrm{ECM}_{\mathrm{For}}=\mathrm{ECM}$ produced from forage. 
SR

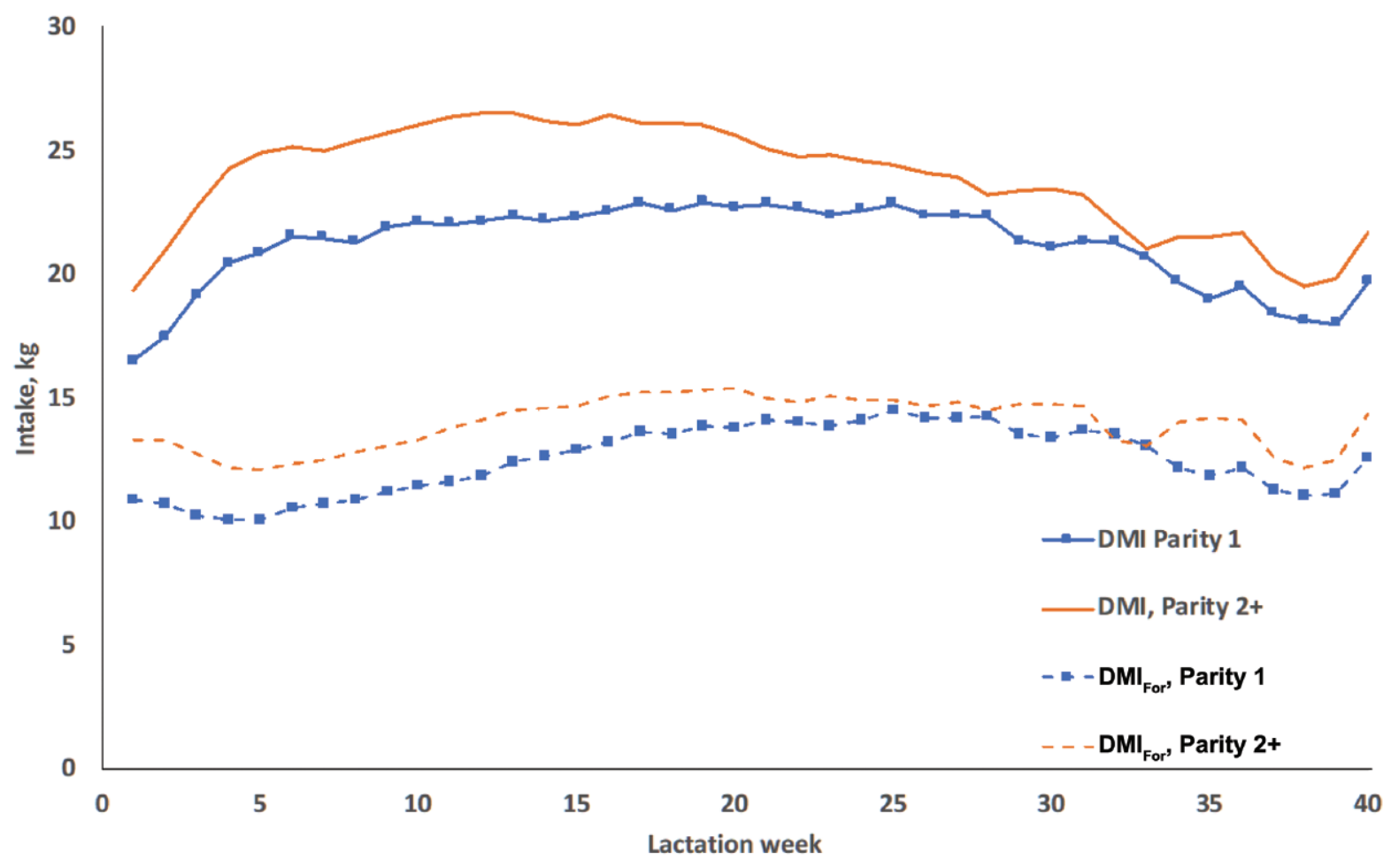

Holstein

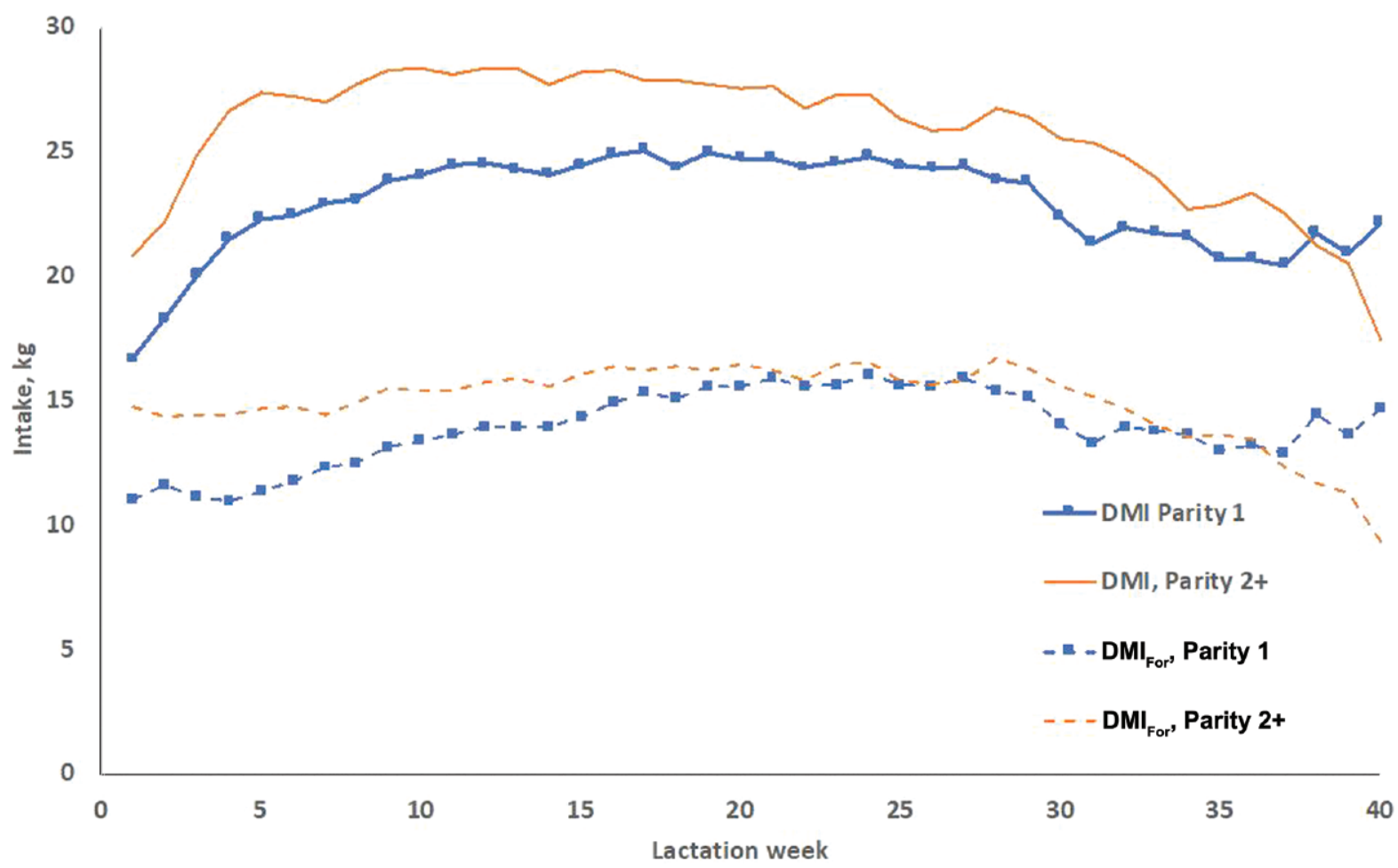

Figure 1. Total DMI and forage DMI (DMI For $)$ across lactation weeks for parities 1 and 2 or higher in Swedish Red (SR; upper panel) and Holstein (lower panel) cows. 
SR

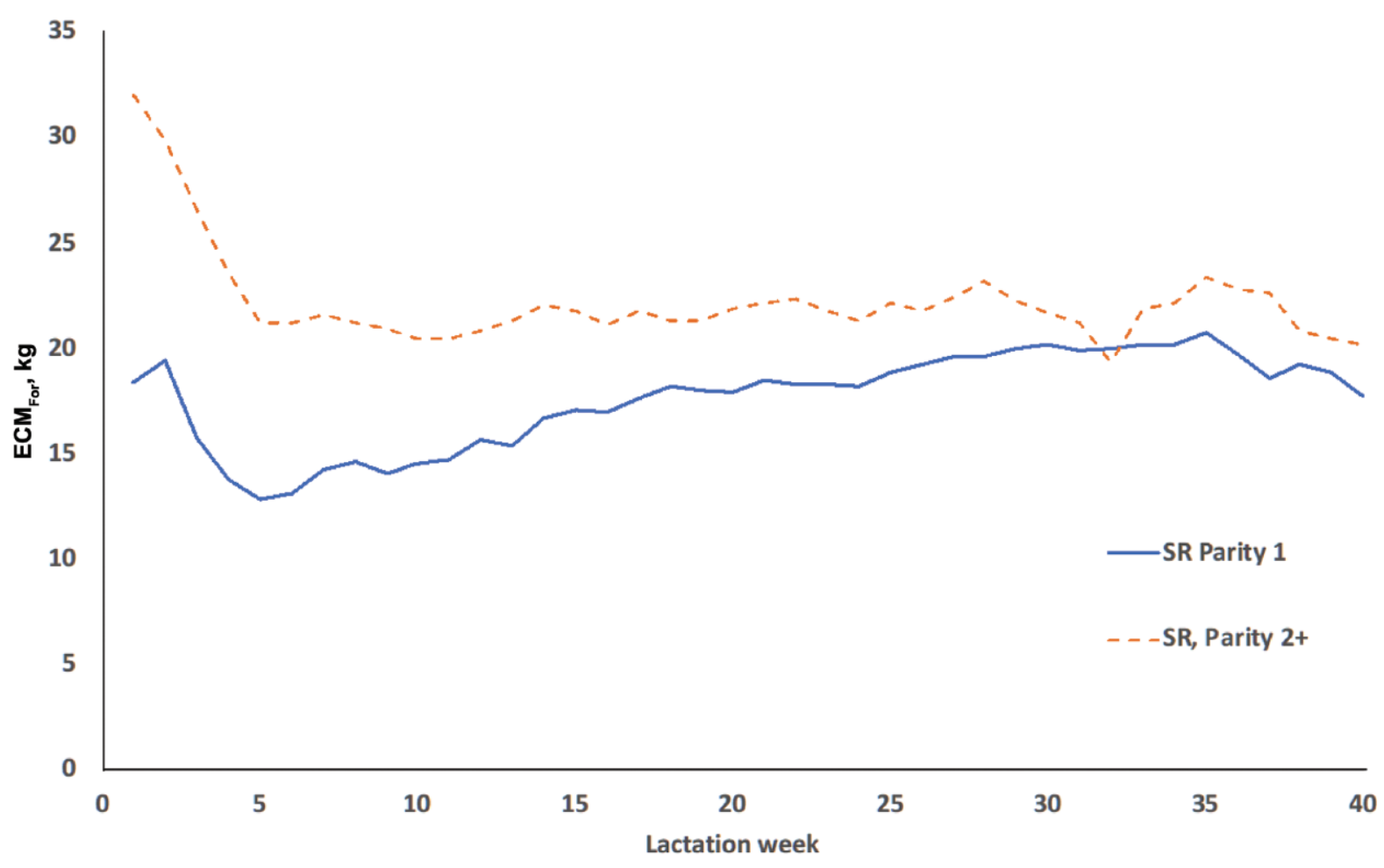

Holstein

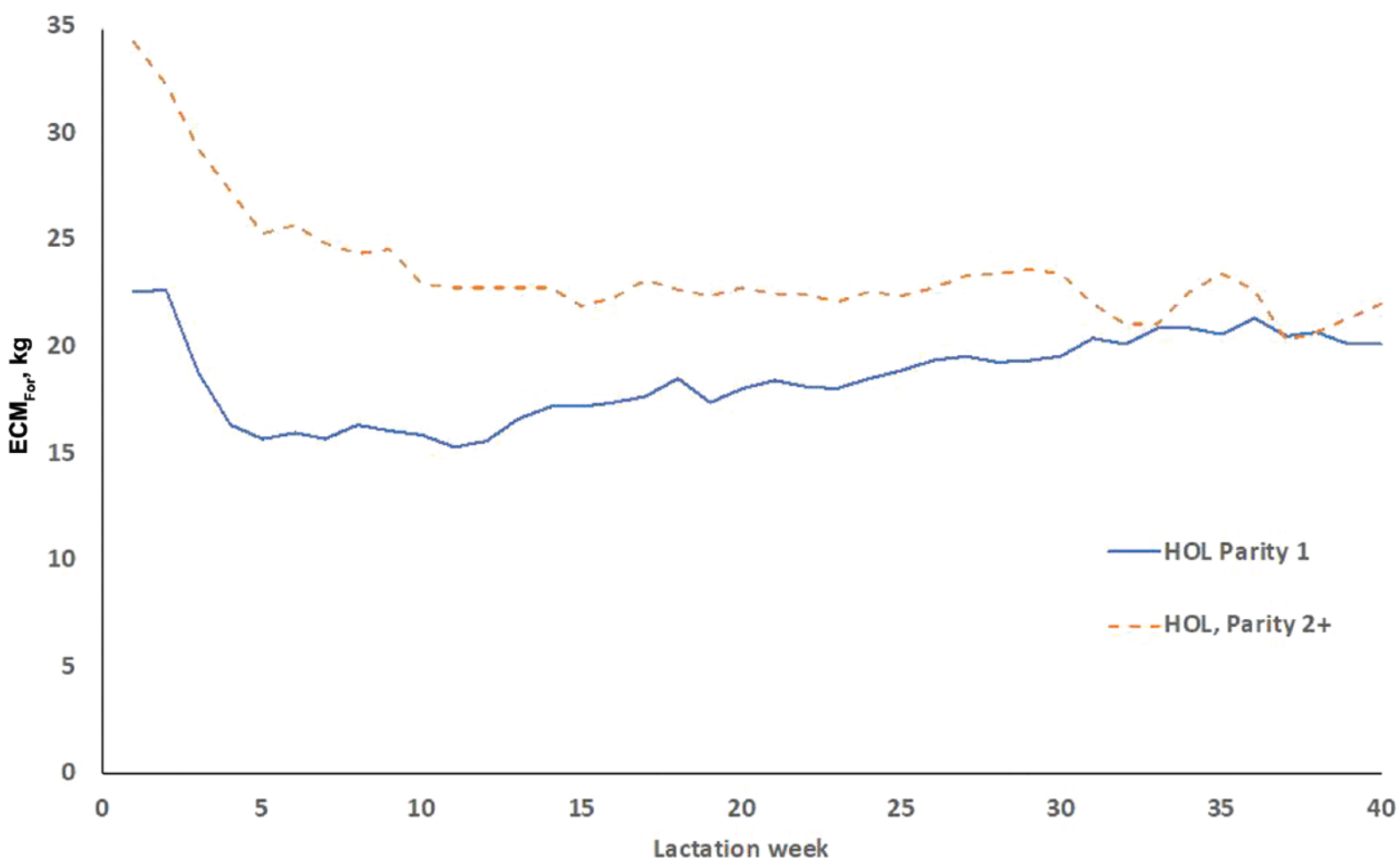

Figure 2. Energy-corrected milk produced from forage $\left(\mathrm{ECM}_{\mathrm{For}}\right)$ across lactation weeks for parities 1 and 2 or higher in Swedish Red (SR; upper panel) and Holstein (HOL; lower panel) cows. 
(higher, lower) do not imply statistically significant differences, but are given to help the reader interpret the results. Because we are using a random regression approach, all parameters were a function of lactation week. To avoid too much information, standard errors of estimates are presented from mid lactation (wk 20-21).

The heritability estimates for DMI and $\mathrm{DMI}_{\text {For }}$ generally followed the same pattern over the lactation (Figures 3, 4, and 5). Heritability was generally higher for HOL than for SR in all-parity data (Figure 3) and in later parities (Figure 5); however, the opposite was true for first parity (Figure 4). For HOL, heritability of DMI and $\mathrm{DMI}_{\mathrm{For}}$ increased with lactation week except in parity 1 , where it was constant or decreased slightly. Heritability for DMI was rather low for SR in all-parity data and in later parities and approached zero in mid lactation; however, it ranged between 0.2 and 0.6 in first parity. During the first 8 wk of lactation, the heritability estimates were more similar across
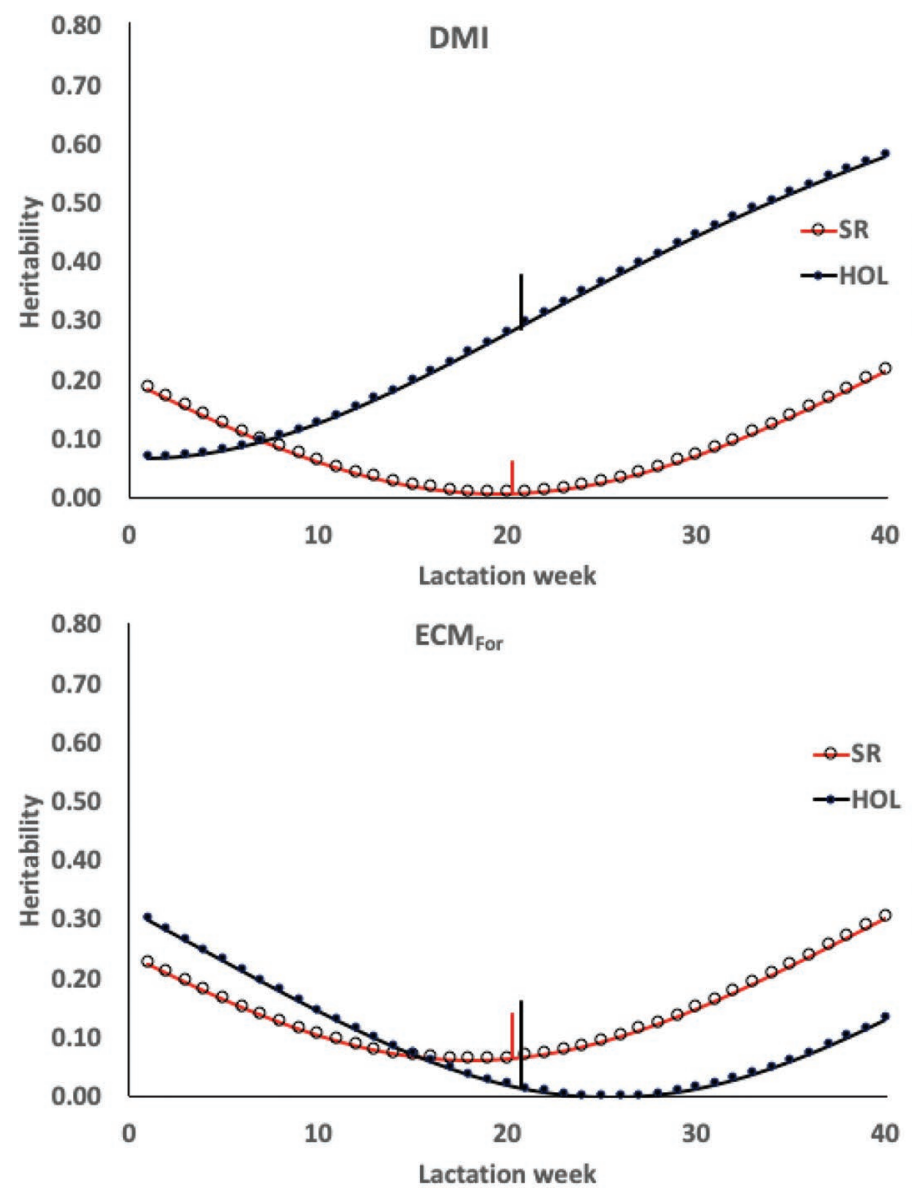

breeds, averaging 0.11 and 0.15 for DMI and $\mathrm{DMI}_{\mathrm{For}}$, respectively (Table 3 ).

Li et al. (2016, 2018) found no systematic differences in heritability for DMI between primiparous HOL, Nordic Red, and Jersey. Heritability estimates ranging from low to high (0.08-0.52) have been reported for DMI over the whole lactation length in HOL cows from 9 countries, including countries from Europe, North America, and Oceania (Berry et al., 2014), and in Dutch and US HOL cows (0.29-0.32; Manzanilla Pech et al., 2016). In the study by Berry et al. (2014), the average heritability across all data sets at d 70 was 0.34 . This is higher than our estimates for HOL in wk 10 at 0.11 .

Previous studies also indicate that DMI heritability can vary across lactation stages in HOL and Nordic Red cows (Berry et al., 2007; Liinamo et al., 2012; Tetens et al., 2014; Manzanilla Pech et al., 2016; Li et al., 2016, 2018). Li et al. (2018), also studying Nordic cattle, reported that genetic variance and heritability for DMI tended to increase within lactation stage, and
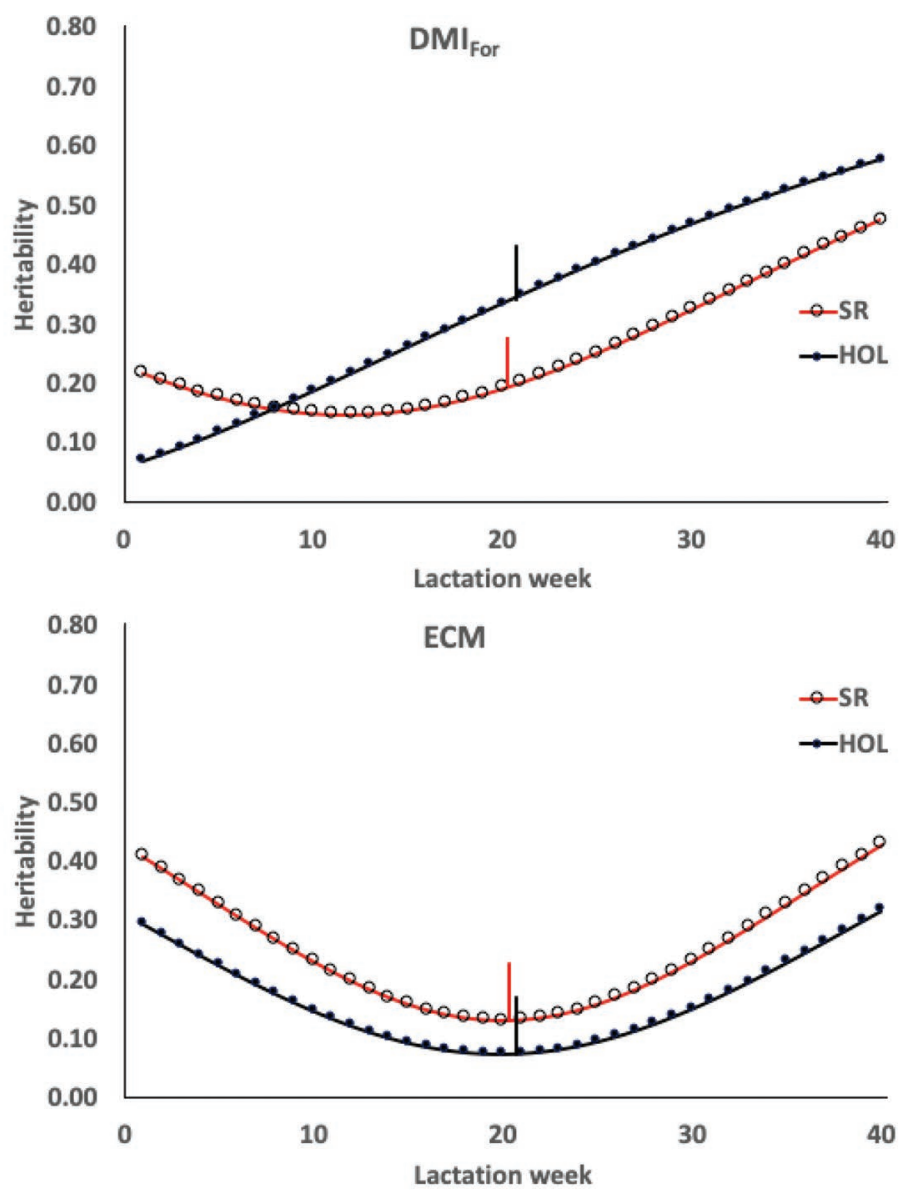

Figure 3. Heritability estimates for total DMI and forage DMI (DMI $\mathrm{For})$, energy-corrected milk produced from forage $\left(\mathrm{ECM}_{\mathrm{For}}\right)$, and $\mathrm{ECM}$ for Swedish Red (SR) and Holstein (HOL) cows as a function of lactation week. Data are from all parities. Standard error is indicated by a vertical line in the middle of the interval. 

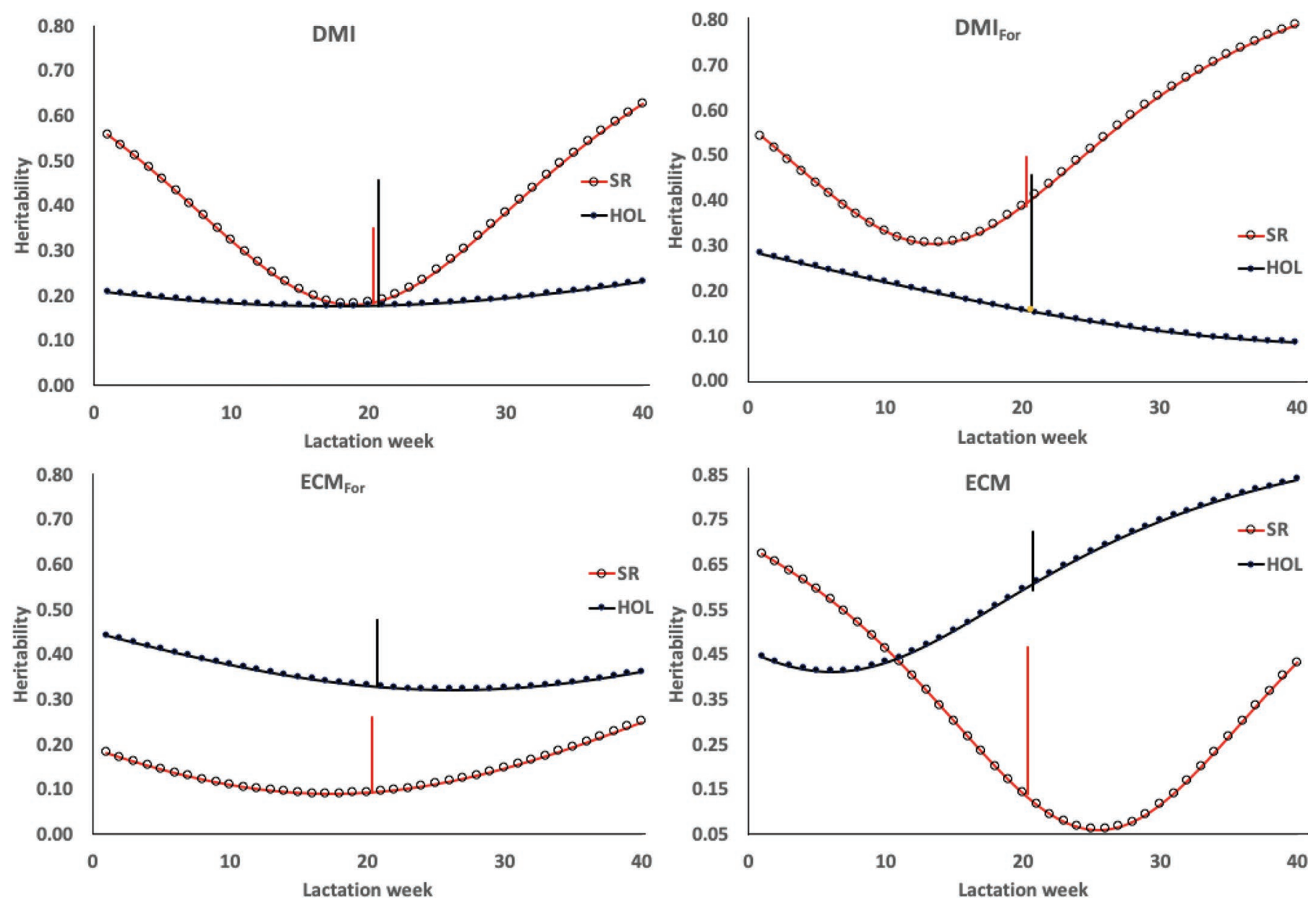

Figure 4. Heritability estimates for total DMI and forage DMI ( $\left.\mathrm{DMI}_{\mathrm{For}}\right)$, energy-corrected milk produced from forage $\left(\mathrm{ECM}_{\mathrm{For}}\right)$, and $\mathrm{ECM}$ for Swedish Red (SR) and Holstein (HOL) cows as a function of lactation week. Data are from parity 1. Standard error is indicated by a vertical line in the middle of the interval.

the permanent environmental variance was relatively stable. Their heritability estimates were higher than ours, ranging from 0.30 to 0.55 over $44 \mathrm{wk}$ for HOL, and from 0.20 to 0.48 over 32 wk for Nordic Red. Liinamo et al. (2012) found higher heritability for DMI in Nordic Red cows in early stages of lactation (wk 2-10) compared with mid-lactation stages. Berry et al. (2007) reported a heritability for grass DMI ranging from 0.10 in the beginning of lactation to a highest value of 0.30 around d 169; whereafter it decreased to around 0.2 at d 300 .

The $\mathrm{ECM}_{\text {For }}$ showed rather low heritability estimates for all-parity data and later-parity data, in some parts of the lactation approaching zero, especially for HOL. However, for SR, the shape and level of the heritability curve was similar for all-parity data and first-parity data. For first parity, HOL showed substantially higher heritability, around 0.3 in mid lactation. The average heritability during the first 8 wk was rather similar for both breeds, 0.18 and 0.24 for SR and HOL, respectively (Table 3 ).

The ECM was not our main interest in this paper, but was analyzed for comparison. Heritability showed a valley-shaped function in all-parity data and in laterparity data with lower heritability in mid lactation, with a similar shape to that for $\mathrm{ECM}_{\mathrm{For}}$. For first parity, the curve for SR was more extreme, going from 0.06 to 0.67 , whereas the curve for HOL generally increased over the lactation, ranging from 0.41 to 0.84 . The average heritability during the first 8 wk was 0.34 and 0.24 for SR and HOL, respectively (Table 3).

Genetic correlations between traits are shown in Figure 6. The correlation between DMI and $\mathrm{DMI}_{\mathrm{For}}$ was high, above 0.83 , and fairly constant across the lactation. The genetic correlation between DMI and $\mathrm{ECM}_{\mathrm{For}}$ and between $\mathrm{DMI}_{\mathrm{For}}$ and $\mathrm{ECM}_{\mathrm{For}}$ was low and negative for HOL (absolute value around 0.2-0.3), but changed for SR from weakly positive in early lactation 

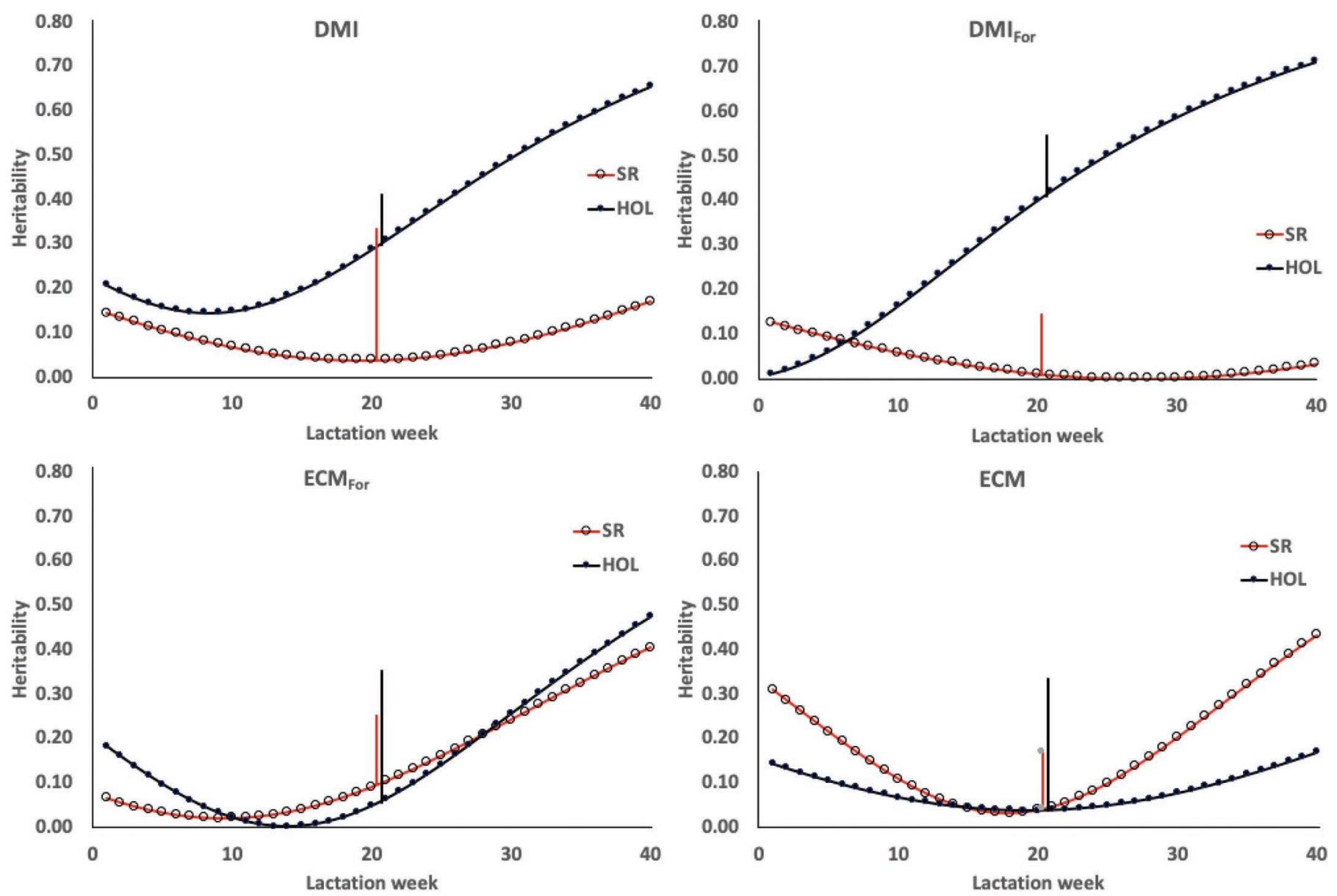

Figure 5. Heritability estimates for total DMI and forage DMI ( $\left.\mathrm{DMI}_{\mathrm{For}}\right)$, energy-corrected milk produced from forage $\left(\mathrm{ECM}_{\mathrm{For}}\right)$, and $\mathrm{ECM}$ for Swedish Red (SR) and Holstein (HOL) cows as a function of lactation week. Data are from later parities. Standard error is indicated by a vertical line in the middle of the interval.

to negative values and back to positive toward the end of lactation. This different behavior for SR was also seen in the correlation between the 2 DMI traits and ECM, which were mostly negative. For HOL, however, there was a weak positive genetic correlation early in lactation, which increased to a high positive value in late lactation. This indicated that $\mathrm{ECM}_{\mathrm{For}}$ was a different trait than $\mathrm{DMI}_{\mathrm{For}}$ (and DMI), especially for HOL.

Hüttman et al. (2009) found a genetic correlation between DMI and milk yield in the first month after calving of 0.44 , which then increased to around 0.8 to 0.9 in mo 4 to 6 , in primiparous HOL. Buttchereit et al.

Table 3. Average heritability estimates (genetic SD in parentheses) for the first 8 wk in lactation for DMI, $\mathrm{DMI}_{\mathrm{For}}, \mathrm{ECM}_{\mathrm{For}}$ and ECM for Swedish Red (SR) and Holstein (HOL) cows and as average across breeds ${ }^{1}$

\begin{tabular}{lcccc}
\hline Parity and breed & DMI & DMI $_{\text {For }}$ & ECM $_{\text {For }}$ & ECM \\
\hline All parities & $0.11(1.10)$ & $0.15(1.22)$ & $0.21(2.68)$ & $0.29(2.65)$ \\
SR & $0.14(1.20)$ & $0.18(1.32)$ & $0.18(2.98)$ & $0.34(2.98)$ \\
HOL & $0.08(1.00)$ & $0.11(1.12)$ & $0.24(2.38)$ & $0.24(2.32)$ \\
First parity & $0.32(1.73)$ & $0.36(1.94)$ & $0.28(2.15)$ & $0.51(2.59)$ \\
SR & $0.45(2.05)$ & $0.47(2.30)$ & $0.15(2.93)$ & $0.60(2.23)$ \\
HOL & $0.20(1.42)$ & $0.26(1.58)$ & $0.42(2.15)$ & $0.42(2.59)$ \\
Later parities & $0.13(1.15)$ & $0.08(1.16)$ & $0.07(1.51)$ & $0.17(2.03)$ \\
SR & $0.10(0.90)$ & $0.11(1.63)$ & $0.04(1.06)$ & $0.23(2.43)$ \\
HOL & $0.17(1.40)$ & $0.06(0.70)$ & $0.11(1.96)$ & $0.11(1.63)$ \\
\hline
\end{tabular}

${ }^{1} \mathrm{DMI}_{\mathrm{For}}=\mathrm{DMI}$ from forage; $\mathrm{ECM}_{\mathrm{For}}=\mathrm{ECM}$ produced from forage. 
(2011), using data from the same bull dam performance testing as Hüttman et al. (2009) but a later and larger material, reported a genetic correlation between DMI and ECM going from around 0 at d 15 to around 0.5 to 0.6 from d 60 to 180 . Li et al. (2018) showed an increasing genetic correlation between DMI and ECM over the lactation, from around 0.2 in early lactation to 0.8 at wk 14 in HOL, and to 0.67 in wk 16 for Nordic Red. For the latter breed, the correlation then decreased somewhat, but remained over 0.5. This increase with lactation stage is similar in our results for HOL (Figure 6), but going from around 0 to almost unity. However, our results for SR are different from those of $\mathrm{Li}$ et al. (2018).

The genetic correlation between $\mathrm{ECM}_{\mathrm{For}}$ and $\mathrm{ECM}$ was close to unity in the later part of lactation for both breeds, but was around 0.8 in the early lactation for both breeds and decreased for HOL to 0.54 in wk 17 . This indicated that the main usefulness of $\mathrm{ECM}_{\mathrm{For}}$ was during the earlier part of the lactation, when there was information that differed from that available in ECM.

The breed difference in the shape of genetic correlations between DMI or $\mathrm{DMI}_{\mathrm{For}}$ on one hand, and $\mathrm{ECM}_{\mathrm{For}}$ or ECM on the other, is interesting. However, as mentioned, all genetic correlations had very large standard errors, and thus care is needed in interpretation. Additional data on $\mathrm{DMI}_{\mathrm{For}}$ and $\mathrm{ECM}_{\mathrm{For}}$ are needed before firm conclusions about breed differences for these traits can be drawn.

Permanent environmental correlations between traits are shown in Figure 7. The correlation between DMI and $\mathrm{DMI}_{\text {For }}$ was generally high, above 0.5. The permanent environmental correlation between DMI and $\mathrm{ECM}_{\text {For }}$ was quite low but generally positive, whereas the correlation between $\mathrm{DMI}_{\mathrm{For}}$ and $\mathrm{ECM}_{\mathrm{For}}$ was rather high (0.5-0.7) for most of the lactation. The correlation between DMI and ECM was around 0.6 for most of the lactation. The correlation between $\mathrm{DMI}_{\mathrm{For}}$ and $\mathrm{ECM}$ was lower, and was rather stable across the lactation for SR. The correlation between $\mathrm{ECM}_{\mathrm{For}}$ and $\mathrm{ECM}$ decreased from around 0.7 to 0.8 early in lactation to rather low, or even slightly negative values, at the end of lactation.

Residual correlations between DMI and $\mathrm{DMI}_{\text {For }}$ were high at above 0.8 (Table 4). The DMI was only weakly, and even slightly negatively, residually correlated with
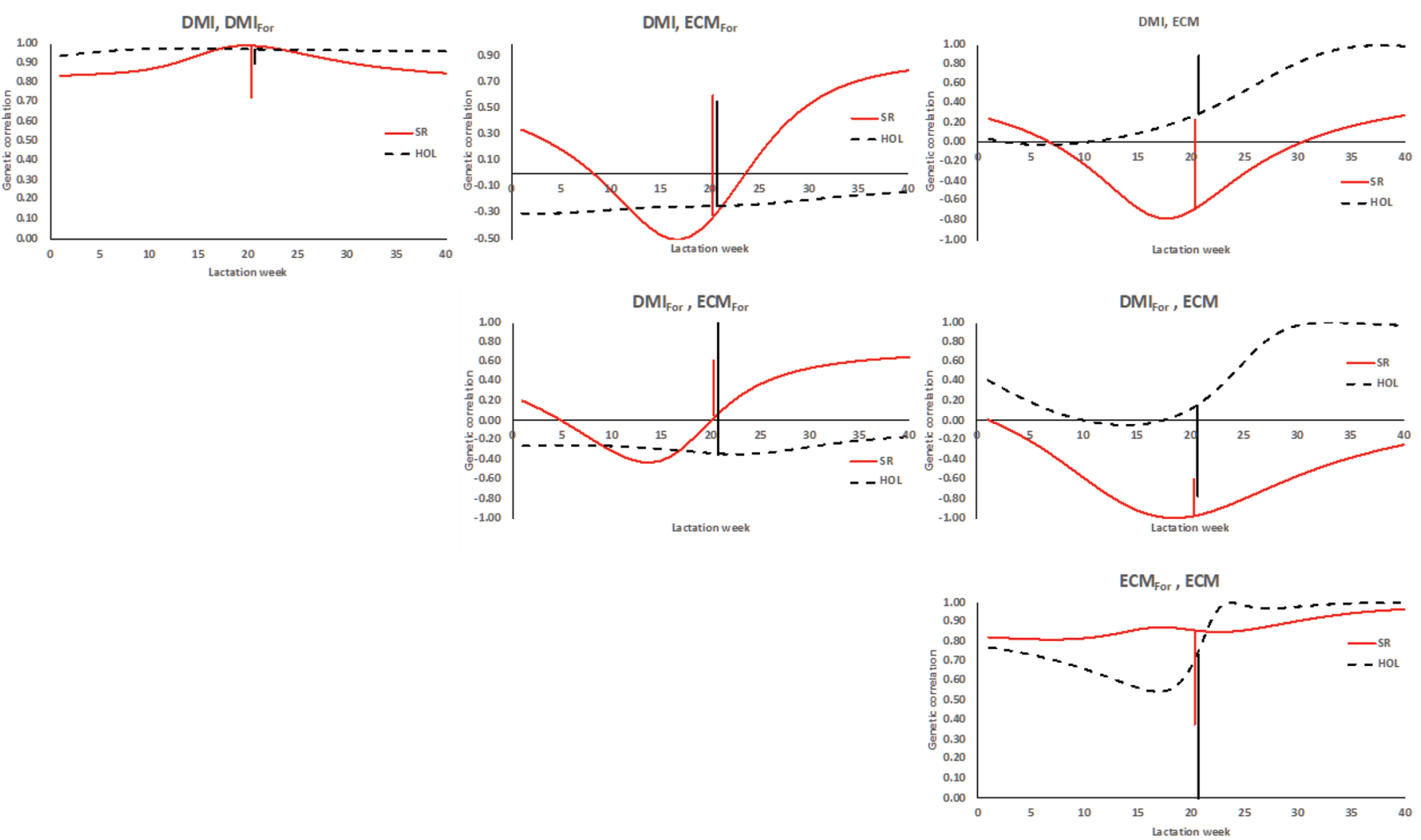

Figure 6. Genetic correlations among total DMI, forage DMI ( $\left.\mathrm{DMI}_{\mathrm{For}}\right)$, energy-corrected milk produced from forage $\left(\mathrm{ECM}_{\mathrm{For}}\right)$, and $\mathrm{ECM}$ for Swedish Red (SR) and Holstein (HOL) cows as a function of lactation week. Data are from all parities. Standard error is indicated by a vertical line in the middle of the interval (for HOL and the combinations $\mathrm{DMI}_{\mathrm{For}}-\mathrm{ECM}_{\mathrm{For}}$ and $\mathrm{ECM}_{\mathrm{For}}$-ECM, the values were 1.4 and 7.3, respectively). 

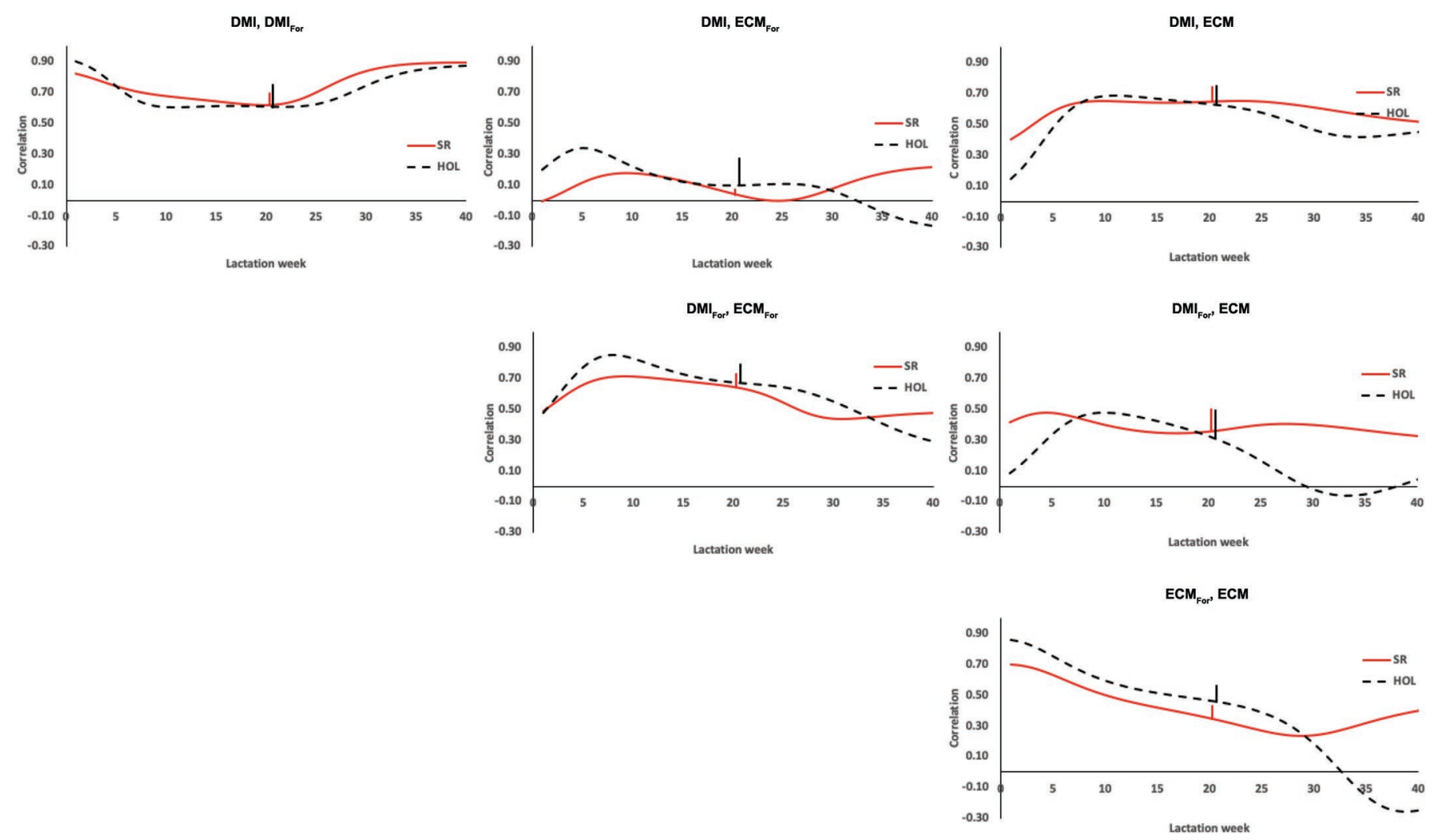

Figure 7. Permanent environmental correlations among total DMI, forage DMI $\left(\mathrm{DMI}_{\mathrm{For}}\right)$, energy-corrected milk produced from forage $\left(\mathrm{ECM}_{\mathrm{For}}\right)$, and ECM for Swedish Red (SR) and Holstein (HOL) cows as a function of lactation week. Data are from all parities. Standard error is indicated by a vertical line in the middle of the interval.

$\mathrm{ECM}_{\mathrm{For}}$. The $\mathrm{DMI}_{\text {For }}$ was more strongly (and positively) residually correlated with $\mathrm{ECM}_{\text {For }}$.

The genetic correlation within the same trait but across lactation weeks is shown in Figure 8. The correlation shown is between the first week and all later weeks. For most traits, the correlation between wk 1 and 2 mo into the lactation (wk 8) was very high, with the lowest for DMI and HOL at 0.81. Some of the correlation curves behaved badly, especially for $\mathrm{ECM}_{\mathrm{For}}$ in HOL, where the correlation went from almost +1 to -1 within a few weeks around wk 25 . This is because

Table 4. Residual correlations ${ }^{1}$ between traits for Swedish Red (above the diagonal) and Holstein (below the diagonal)

\begin{tabular}{lrccc}
\hline & \multicolumn{4}{c}{ Trait } \\
\cline { 2 - 5 } Trait $^{2}$ & DMI & $\mathrm{DMI}_{\text {For }}$ & $\mathrm{ECM}_{\text {For }}$ & ECM \\
\hline DMI & - & 0.82 & -0.16 & 0.28 \\
DMI $_{\text {For }}$ & 0.86 & - & 0.23 & 0.12 \\
ECM $_{\text {For }}$ & -0.09 & 0.26 & - & 0.53 \\
ECM & 0.28 & 0.15 & 0.56 & - \\
\hline
\end{tabular}

${ }^{1}$ Standard errors for all residual correlations were $\leq 0.01$.

${ }^{2} \mathrm{DMI}_{\mathrm{For}}=\mathrm{DMI}$ from forage; $\mathrm{ECM}_{\mathrm{For}}=\mathrm{ECM}$ produced from forage. heritability goes to 0 in that lactation stage (Figure 3 ). This means that all breeding value regressions meet at 1 point, which leads to a total reranking after that point. There was a similar but less extreme curve for DMI for SR. Thus, it is probably unwise to put too much faith in the correlations between 2 time points far away from each other. With a larger data set, it might be possible to also use a quadratic regression for the breeding values, which might avoid this behavior.

For DMI, Tetens et al. (2014) also found a high genetic correlation between first measurement at d 11 and a decline of the correlation between measurements at $\mathrm{d}$ 11 with later measurements up to d 180 in primiparous HOL. This shape was quite similar to that in Figure 8 for HOL. Their records ended at d 180. The decay of the genetic correlation between wk 1 and later weeks in Veerkamp and Thompson (1999) was also similar to our results, where comparable (up to 15 wk). Spurlock et al. (2012) found very high genetic correlation between DMI at d 10 and DIM up to d 150 (close to 0.9). On the other hand, Karacaören et al. (2006) found a rapidly decreasing genetic correlation between $\mathrm{d} 1$ and later DIM, turning to weakly negative around d 110 . 
One important issue is whether the focus should be on improving forage intake during the whole lactation, or whether a certain period should be targeted, as this could determine the period or periods in which data collection should take place. Collecting observations of forage intake throughout entire lactations for genetic evaluation may not be feasible, even if special equipment is available. Our results, with respect to heritabilities and genetic correlations within the lactation, indicated that generating feed intake data during the first 2 mo might be sufficient for genetic evaluation for both DMI and $\mathrm{DMI}_{\mathrm{For}}$. The lowest average heritability was 0.08 (HOL DMI), and the lowest genetic correlation between the first and eighth weeks was 0.81 for all parities. For first parity, corresponding lowest values were 0.20 and 0.92 , respectively. On the other hand, Li et al. (2018) found that early DMI had a relatively low genetic correlation with DMI in mid or late lactation, but that there were stronger correlations within mid- and late-lactation values. Liinamo et al. (2012) found that DMI in early lactation had poor predictive ability of later DMI, which they hypothesized could be associated with the cows starting their reproductive cycles again. Thus, these latter results would indicate a need to record DMI during a longer period. However, if concentrate feed is recorded routinely over the whole lactation, it would not be more difficult to measure $\mathrm{ECM}_{\text {For }}$ during the whole lactation. If this is the basis for creating a reference population to estimate genomic breeding values, then waiting longer for data would not delay selection decisions severely.

Another issue is whether the traits need to be recorded in all lactations or if it is enough with first parity data. Arguably, the capacity for a large intake could be more critical in later parities when the negative energy balance is most likely larger (e.g., Friggens et al., 2007). In our results, heritability in first parity tended to be higher than in later parities, which indicated that it would be easier to achieve high accuracy in first parity. However, if the breeding goal is to improve DMI, $\mathrm{DMI}_{\mathrm{For}}$, or $\mathrm{ECM}_{\mathrm{For}}$ in all parities, then the genetic correlation between first and later parities should be high.

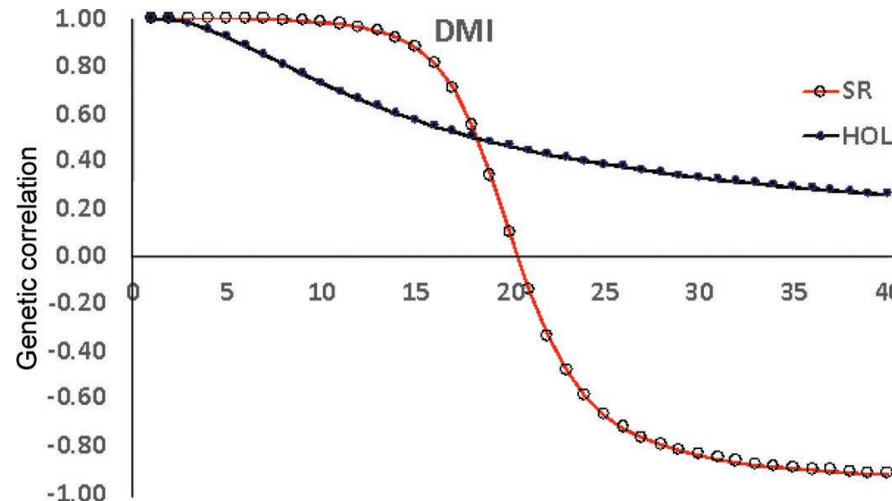

Lactation week

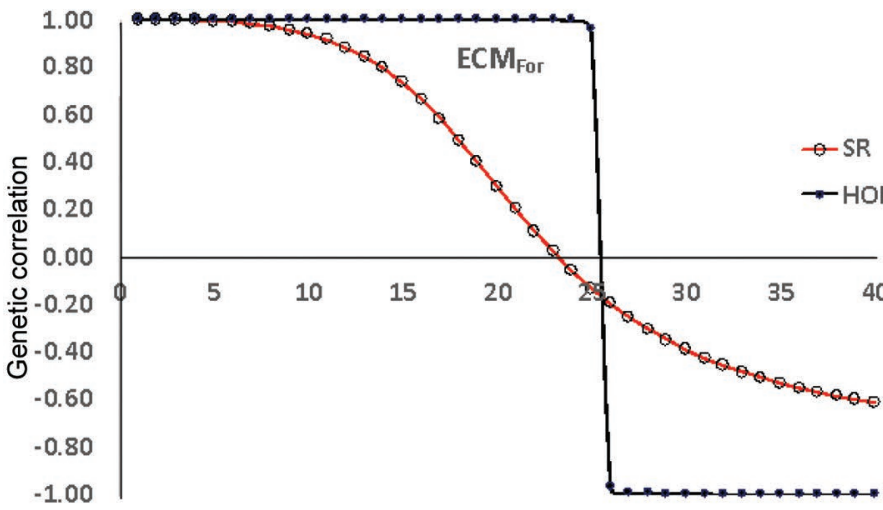

Lactation week

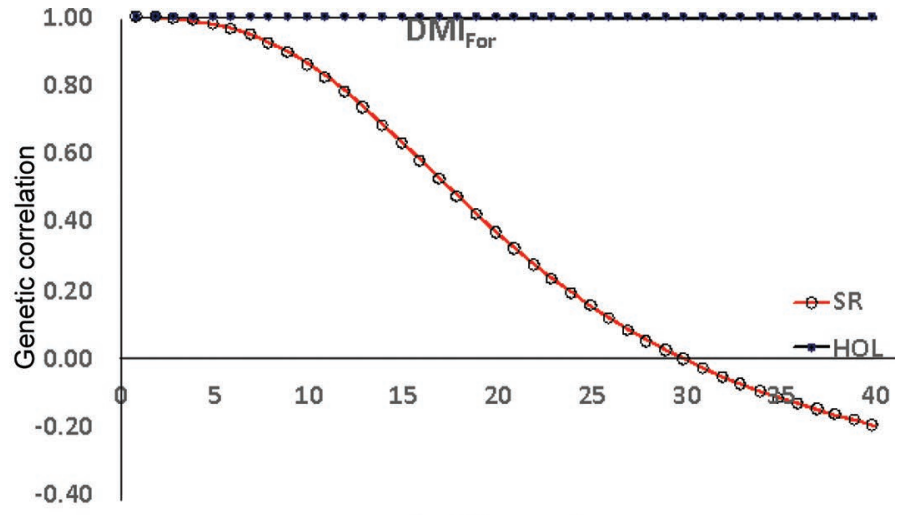

Lactation week

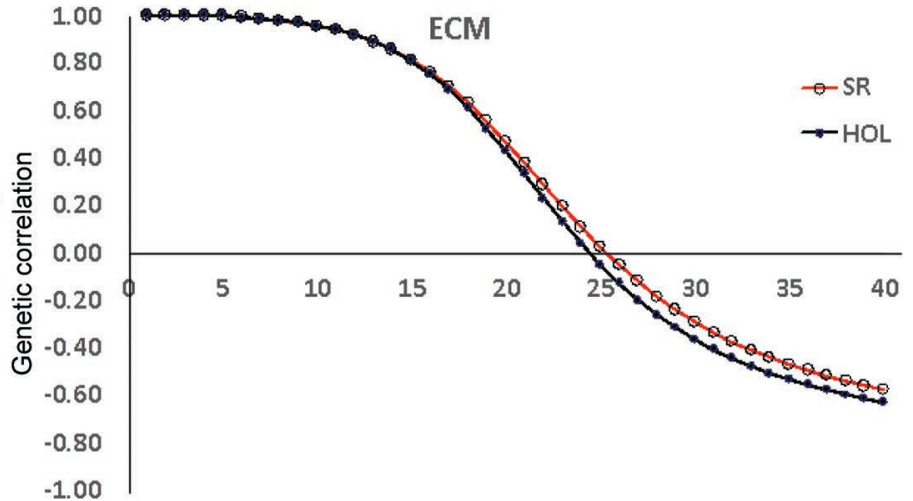

Lactation week

Figure 8. Genetic correlations between wk 1 and later lactation weeks for total DMI, forage DMI (DMI ${ }_{\text {For }}$ ), energy-corrected milk produced from forage $\left(\mathrm{ECM}_{\mathrm{For}}\right)$, and $\mathrm{ECM}$ for Swedish Red (SR) and Holstein (HOL) cows. Data are from all parities. 

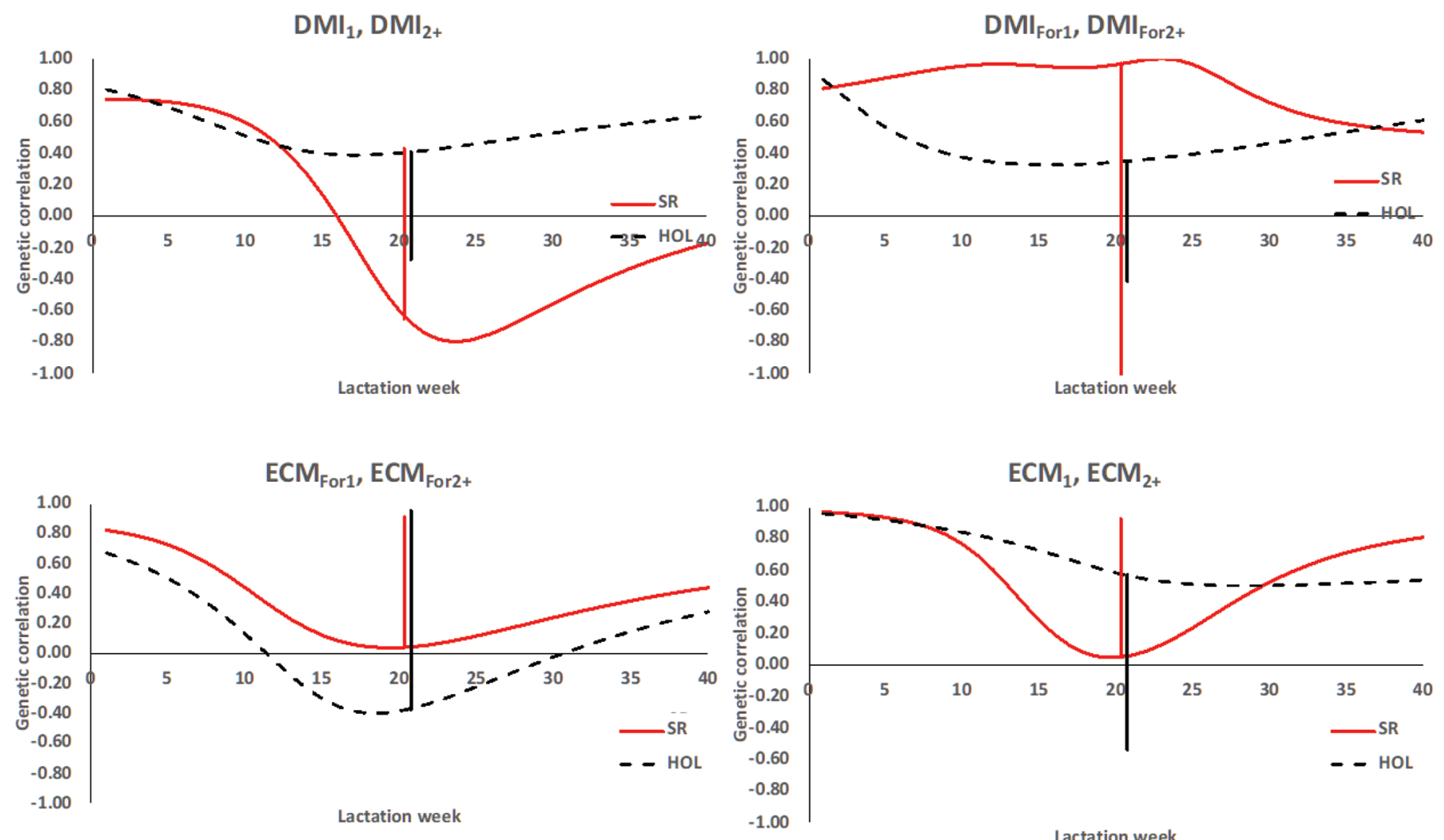

Figure 9. Genetic correlations between parity 1 and later parities $(2+)$ for total DMI, forage DMI (DMI $\left.{ }_{\mathrm{For}}\right)$, energy-corrected milk produced from forage $\left(\mathrm{ECM}_{\mathrm{For}}\right)$, and ECM for Swedish Red (SR) and Holstein (HOL) cows. Standard error is indicated by a vertical line in the middle of the interval (for $\mathrm{SR}$ and $\mathrm{DMI}_{\mathrm{For}}$, $\mathrm{SE}$ was 11.3). For SR $\mathrm{DMI}_{\mathrm{For}}$, the variance-covariances from the univariate analyses were kept for first parity; for SR DMI, they were also kept for second parity to achieve convergence.

The genetic correlation estimates between parity 1 and later parities are shown in Figure 9. The correlation was rather high in the first part of the lactation. During the first $8 \mathrm{wk}$, the correlation was lower for HOL than for SR. Thus, if the main aim is to improve the trait in early lactation, then it would possibly be a reasonable first step to only use information from first parity.

\section{General Comments}

The trait $\mathrm{ECM}_{\text {For }}$ has some potential advantages, but also some weaknesses. In the material available for this study, we were only able to adjust very crudely for maintenance requirements. The accuracy could be improved if individual weight records, also over the lactation period, were available. We had few repeated weight records in general and, for some cows, we also saw a large variation (almost $100 \mathrm{~kg}$ ) in weight, even between 2 consecutive days. This most likely reflected whether the cow had recently been eating and drinking or not. Therefore, a single weight record can be misleading. Another weakness in the current definition of $\mathrm{ECM}_{\mathrm{For}}$ is that we could not account for the energy used for, or derived from, body reserves. For this, we would need recurrent BCS (in addition to weight data). We presumably overestimated $\mathrm{ECM}_{\text {For }}$ during early lactation and underestimated it during later lactation stages, but probably to differing extents for different cows. Furthermore, various other experiments, including some related to feeding, were carried out on this particular herd during the study period. For 2 main reasons, it was not possible to adjust for possible treatment to which a cow was subjected at a given time. First, it was difficult to find out what treatment was being applied and, second, sometimes more than 1 treatment was applied to the same cows. This meant that the residual variance was higher in this herd than in a normal commercial herd, which would decrease the heritability. This weakness is also relevant for the traits DMI and $\mathrm{DMI}_{\mathrm{For}}$.

One advantage of $\mathrm{ECM}_{\mathrm{For}}$ is that it combines the ability to eat large amounts of forage with capacity for high milk yield, which DMI or DMI $\mathrm{Dor}_{\text {Fo }}$ does not. Therefore, it could be an easier trait to use for selection to produce animals with good capacity to produce milk on a forage diet. Differences in $\mathrm{ECM}_{\mathrm{For}}$ between cows could also 
be more closely related to differences in profit margin because the feed costs are lower for forage. Arguably, this trait could be especially desirable for (Swedish) organic producers, as they have been shown to prioritize roughage intake more than conventional dairy producers (Ahlman et al., 2014). Additionally, Slagboom et al. (2018) showed that a breeding goal based on organic principles would put more emphasis on roughage intake than done in the current breeding goals in Denmark, Finland, and Sweden. To improve $\mathrm{DMI}_{\text {For }}$, DMI seems to be a good proxy; however, it is not a good proxy for improving $\mathrm{ECM}_{\mathrm{For}}$.

Another advantage of $\mathrm{ECM}_{\mathrm{For}}$, provided that the herd has separate forage and concentrate feeding, is that it is easier to get records of concentrate feeding than it is to measure forage intake. The energy content of concentrate is also less variable than that of forage. Therefore, it should be easier to collect data on $\mathrm{ECM}_{\mathrm{For}}$ (e.g., for setting up a reference population for genomic evaluation) than for $\mathrm{DMI}_{\mathrm{For}}$. Another advantage is that $\mathrm{ECM}_{\text {For }}$ would be meaningful during summer, when much of the energy intake comes from pasture. Thus, it would be interesting to develop the trait further in more herds with concentrate feeding records. With a larger data set, it would also be possible to obtain more precise estimates of genetic parameters, especially genetic correlations with other traits in the breeding goal.

Despite the difficulty in making comparisons with literature data, especially for $\mathrm{DMI}_{\mathrm{For}}$ and $\mathrm{ECM}_{\mathrm{For}}$, our findings support the suggestion of considering measures related to feed intake in selection indices in breeding programs. The focus should perhaps be especially on forage intake traits, considering the unique ability of ruminants to digest plants that humans cannot eat and convert them into high-quality food for humans. The levels of heritability found here for $\mathrm{DMI}_{\text {For }}$ and $\mathrm{ECM}_{\mathrm{For}}$ indicate that genetic selection for these traits is feasible in SR and HOL cows, provided that routine measurements of the traits can be made. It should be noted that all heritability estimates presented here were defined for 1 weekly average, and having several weekly values would increase the accuracy substantially. However, a follow-up study with a larger data set is suggested to improve the precision of the parameter estimates and to explore the possibility of genomic evaluations. Studies on genetic correlations with other traits in the breeding goal would also be of interest.

\section{CONCLUSIONS}

Increasing dairy cow forage intake could help reduce costs in milk production and make the dairy industry more socially acceptable. High accuracy of selection can be achieved if forage or concentrate intake data are rou- tinely available and if traits of interest have reasonable heritability. When using random regression analysis, estimates of all parameters vary over the lactation, thus making it difficult to summarize in words. If we restrict ourselves to the first $8 \mathrm{wk}$, heritability for DMI, DMI $\mathrm{For}_{\text {, }}$, $\mathrm{ECM}_{\text {For }}$, and ECM averaged 0.11, 0.15, 0.21, and 0.29, respectively, in all-parity data. In first parity, values were $0.32,0.36,0.28$, and 0.51 , respectively. These heritability estimates were based on single observations of weekly averages, and accuracy of breeding values could be substantially increased with more observations. Although DMI and $\mathrm{DMI}_{\text {For }}$, as well as ECM and $\mathrm{ECM}_{\mathrm{For}}$, were quite strongly correlated, they were not genetically identical, especially not in the early lactation. It

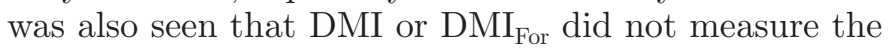
same genetic variation as $\mathrm{ECM}_{\mathrm{For}}$. It seems that, generally, the genetic correlation between first and later parities is rather high, at least in early lactation, and that early measures are strongly correlated with each other, but not with measurements later during the lactation. Based on the data set used, $\mathrm{DMI}_{\mathrm{For}}$ or $\mathrm{ECM}_{\mathrm{For}}$, based on known forage or concentrate intake, are possible candidate traits for selection. However, validation with a larger data set is recommended.

\section{ACKNOWLEDGMENTS}

The authors thank the staff at the Swedish Livestock Research Centre (Uppsala, Sweden) for managing the animals, and the laboratory staff at the Department of Animal Nutrition and Management at the Swedish University of Agricultural Sciences (Uppsala, Sweden) for the laboratory analyses. This study was funded by Formas (Stockholm, Sweden) and Stiftelsen Lantbruksforskning (SLF, Stockholm, Sweden). The authors have not stated any conflicts of interest.

\section{REFERENCES}

Ahlman, T., M. Ljung, L. Rydhmer, H. Röcklinsberg, E. Strandberg, and A. Wallenbeck. 2014. Differences in preferences for breeding traits between organic and conventional dairy producers in Sweden. Livest. Sci. 162:5-14. https://doi.org/10.1016/j.livsci.2013.12 .014 .

Åkerlind, M., M. Weisbjerg, T. Eriksson, P. Udén, B. L. Ólafsson, O. Harstad, and H. Volden. 2011. Feed analyses and digestion methods. Pages 41-54 in NorFor-The Nordic Feed Evaluation System. Vol. 130. H. Volden, ed. Wageningen Academic Publishers, Wageningen, the Netherlands.

Arefaine, H., and J. Bertilsson. 2015. Feeding of high forage diet to enhance conjugated linoliec acid (CLA) in cow's milk interest of human health: A review. J. Nat. Sci. Res. 5:17.

Berry, D. P., M. P. Coffey, J. E. Pryce, Y. de Haas, P. Lövendahl, N. Krattenmacher, J. J. Crowley, Z. Wang, D. Spurlock, K. Weigel, K. Macdonald, and R. F. Veerkamp. 2014. International genetic evaluations for feed intake in dairy cattle through the collation of data from multiple sources. J. Dairy Sci. 97:3894-3905. https://doi .org/10.3168/jds.2013-7548. 
Berry, D. P., B. Horan, M. O'Donovan, F. Buckley, E. Kennedy, M. McEvoy, and P. Dillon. 2007. Genetics of grass dry matter intake, energy balance, and digestibility in grazing Irish dairy cows. J. Dairy Sci. 90:4835-4845. https://doi.org/10.3168/jds.2007-0116.

Boddugari, K., R. J. Grant, R. Stock, and M. Lewis. 2001. Maximal replacement of forage and concentrate with a new wet corn milling product for lactating dairy cows. J. Dairy Sci. 84:873-884. https:/ /doi.org/10.3168/jds.S0022-0302(01)74545-6.

Buttchereit, N., E. Stamer, W. Junge, and G. Thaller. 2011. Short communication: Genetic relationships among daily energy balance, feed intake, body condition score, and fat to protein ratio of milk in dairy cows. J. Dairy Sci. 94:1586-1591. https://doi.org/10 $.3168 /$ jds.2010-3396.

Chase, L. E., and R. J. Grant. 2013. High forage rations - What do we know. Proc. Cornell Nutr. Conf., Syracuse, NY. Cornell University, Ithaca, NY.

de Jong, G., R. Van Der Linde, Y. de Haas, G. C. B. Schopen, and R. F. Veerkamp. 2016. Genetic Evaluation for Feed Intake in the Netherlands and Flanders, Impact on Efficiency and Responses. Pages 1-4 in interbull bulletin no. 50. Puerto Varas, Chile.

EEA. 2021. European Environment Agency. Climate change mitigation. Accessed Jan. 28, 2021. https://www.eea.europa.eu/themes/ climate.

Eriksson, S., S. Sanne, and S. Tomke. 1976. Fodermedelstabeller och utfodringsrekommendationer till idisslare, hästar och svin, 2:a uppl., Stockholm, Sweden.

Ertl, P., Q. Zebeli, W. Zollitsch, and W. Knaus. 2015. Feeding of byproducts completely replaced cereals and pulses in dairy cows and enhanced edible feed conversion ratio. J. Dairy Sci. 98:1225-1233. https://doi.org/10.3168/jds.2014-8810.

Ertl, P., Q. Zebeli, W. Zollitsch, and W. Knaus. 2016. Feeding of wheat bran and sugar beet pulp as sole supplements in high-forage diets emphasizes the potential of dairy cattle for human food supply. J. Dairy Sci. 99:1228-1236. https://doi.org/10.3168/jds.2015 $-10285$.

European Commission. 2013. Analysis of milk margins. Pages 8-26 in EU Dairy Farms Report 2013. European Commission on Agricultural and Rural Development. European Commission, European Union.

FAO. 2014. World Mapping of Animal Feeding Systems in the Dairy Sector. FAO, Rome, Italy.

Friggens, N. C., P. Berg, P. Theilgaard, I. R. Korsgaard, K. L. Ingvartsen, P. Løvendahl, and J. Jensen. 2007. Breed and parity effects on energy balance profiles through lactation: Evidence of genetically driven body energy change. J. Dairy Sci. 90:5291-5305. https: //doi.org/10.3168/jds.2007-0173.

Hüttmann, H., E. Stamer, W. Junge, G. Thaller, and E. Kalm. 2009. Analysis of feed intake and energy balance of high-yielding first lactating Holstein cows with fixed and random regression models. Animal 3:181-188. https://doi.org/10.1017/S175173110800325X.

Karacaören, B., F. Jaffrézic, and H. N. Kadarmideen. 2006. Genetic parameters for functional traits in dairy cattle from daily random regression models. J. Dairy Sci. 89:791-798. https://doi.org/10 .3168/jds.S0022-0302(06)72141-5.

Karlsson, J., M. Lindberg, M. Åkerlind, and K. Holtenius. 2020. Whole-lactation feed intake, milk yield, and energy balance of Holstein and Swedish Red dairy cows fed grass-clover silage and two levels of byproduct-based concentrate. J. Dairy Sci. 103:89228937. https://doi.org/10.3168/jds.2020-18204.

Karlsson, J., R. Spörndly, M. Lindberg, and K. Holtenius. 2018. Replacing human-edible feed ingredients with by-products increases net food production efficiency in dairy cows. J. Dairy Sci. 101:7146-7155. https://doi.org/10.3168/jds.2017-14209.

Koenen, E. P. C., and R. F. Veerkamp. 1998. Genetic covariance functions for live weight, condition score, and dry-matter intake measured at different lactation stages of Holstein Friesian heifers. Livest. Prod. Sci. 57:67-77. https://doi.org/10.1016/S0301 -6226(98)00159-6.

Li, B. 2018. Genetic properties of feed efficiency and related traits in dairy cattle. Phd thesis. Department of Animal Breeding and Ge- netics, Faculty of Veterinary Medicine and Animal Science, Swedish University of Agricultural Sciences, Uppsala Sweden.

Li, B., B. Berglund, W. F. Fikse, J. Lassen, M. H. Lidauer, P. Mäntysaari, and P. Løvendahl. 2017. Neglect of lactation stage leads to naive assessment of residual feed intake in dairy cattle. J. Dairy Sci. 100:9076-9084. https://doi.org/10.3168/jds.2017-12775.

Li, B., W. F. Fikse, J. Lassen, M. H. Lidauer, P. Løvendahl, P. Mäntysaari, and B. Berglund. 2016. Genetic parameters for dry matter intake in primiparous Holstein, Nordic Red, and Jersey cows in the first half of lactation. J. Dairy Sci. 99:7232-7239. https://doi.org/ 10.3168/jds.2015-10669.

Li, B., W. F. Fikse, P. Løvendahl, J. Lassen, M. H. Lidauer, P. Mäntysaari, and B. Berglund. 2018. Genetic heterogeneity of feed intake, energy-corrected milk, and body weight across lactation in primiparous Holstein, Nordic Red, and Jersey. J. Dairy Sci. 101:10011-10021. https://doi.org/10.3168/jds.2018-14611.

Liinamo, A.-E., P. Mäntysaari, and E. A. Mäntysaari. 2012. Short communication: Genetic parameters for feed intake, production, and extent of negative energy balance in Nordic Red dairy cattle. J. Dairy Sci. 95:6788-6794. https://doi.org/10.3168/jds.2012-5342.

Lindgren, E. 1983. New calibration of the VOS-method to estimate energy value of forage. Department of Animal Nutrition and Management, Swedish University of Agricultural Sciences, Uppsala, Sweden [In Swedish].

Madsen, P., and J. Jensen. 2013. DMU - A Package for Analyzing Multivariate Mixed Models in Quantitative Genetics and Genomics Center for Quantitative Genetics and Genomics (QGG), Aarhus University, Tjele, Denmark.

Manzanilla Pech, C. I. V., R. F. Veerkamp, M. P. L. Calus, J. E. Pryce, and Y. de Haas. 2014b. Genetic parameters and accuracy of recording dry matter intake in first parity Holstein-Friesian cows. Page 554 in Proceedings of the 10th WCGALP Conference, Vancouver, BC, Canada. Am. Soc. Anim. Sci., Champaign, IL.

Manzanilla Pech, C. I. V., R. F. Veerkamp, M. P. L. Calus, R. Zom, A. van Knegsel, J. E. Pryce, and Y. de Haas. 2014a. Genetic parameters across lactation for feed intake, fat- and protein-corrected milk, and live weight in first-parity Holstein cattle. J. Dairy Sci. 97:5851-5862. https://doi.org/10.3168/jds.2014-8165.

Manzanilla-Pech, C. I. V., R. F. Veerkamp, R. J. Tempelman, M. L. van Pelt, K. A. Weigel, M. VandeHaar, T. J. Lawlor, D. M. Spurlock, L. E. Armentano, C. R. Staples, M. Hanigan, and Y. de Haas. 2016. Genetic parameters between feed-intake-related traits and conformation in 2 separate dairy populations - The Netherlands and United States. J. Dairy Sci. 99:443-457. https://doi.org/10 3168/jds.2015-9727.

NAV. 2020. Nordic Cattle Genetic Evaluation homepage. Accessed Jun. 26, 2020. https://www.nordicebv.info/saved-feed/.

Patel, M. 2012. Effects of increasing the proportion of high-quality grass silage in the diet of dairy cows. PhD Thesis. Department of Animal Nutrition and Management, Swedish University of Agricultural Science, Uppsala, Sweden.

Pryce, J. E., T. T. T. Nguyen, M. Axford, G. Nieuwhof, and M. Shaffer. 2018. Symposium review: Building a better cow-The Australian experience and future perspectives. J. Dairy Sci. 101:37023713. https://doi.org/10.3168/jds.2017-13377.

Randby, Å. T., M. R. Weisbjerg, P. Nørgaard, and B. Heringstad. 2012. Early lactation feed intake and milk yield responses of dairy cows offered grass silages harvested at early maturity stages. J. Dairy Sci. 95:304-317. https://doi.org/10.3168/jds.2011-4454.

SAS. 2012. SAS/STAT 12.1 User's Guide. SAS Institute Inc., Cary, $\mathrm{NC}$

Sjaunja, L. O., L. Baevre, L. Junkkarinen, J. Pedersen, and J. Setälä. 1990. A Nordic proposal for an energy corrected milk (ECM) formula. Pages 156-157 in Proceedings of the 27th Biennial Session of the International Committee for Animal Recording (ICAR), Paris, France. Pudoc, Wageningen, the Netherlands.

SJVFS. 2011. Code of Statutes, Regulations and common advice concerning feed. 2011:40, Saknr M39. The Swedish Board of Agriculture, Jönköping, Sweden. [In Swedish]. 
Slagboom, M., A. Wallenbeck, L. Hjortø, A. C. Sørensen, L. Rydhmer, J. R. Thomasen, and M. Kargo. 2018. Simulating consequences of choosing a breeding goal for organic dairy production. J. Dairy Sci. 101:11086-11096. https://doi.org/10.3168/jds.2017-14316.

Spurlock, D. M., J. C. M. Dekkers, R. Fernando, D. A. Koltes, and A. Wolc. 2012. Genetic parameters for energy balance, feed efficiency, and related traits in Holstein cattle. J. Dairy Sci. 95:5393-5402. https://doi.org/10.3168/jds.2012-5407.

Tetens, J., G. Thaller, and N. Krattenmacher. 2014. Genetic and genomic dissection of dry matter intake at different lactation stages in primiparous Holstein cows. J. Dairy Sci. 97:520-531. https://doi .org/10.3168/jds.2013-7301.

Vallimont, J. E., C. D. Dechow, J. M. Daubert, M. W. Dekleva, J. W. Blum, C. M. Barlieb, W. Liu, G. A. Varga, A. J. Heinrichs, and C. R. Baumrucker. 2010. Genetic parameters of feed intake, production, body weight, body condition score, and selected type traits of Holstein cows in commercial tie-stall barns. J. Dairy Sci. 93:4892-4901. https://doi.org/10.3168/jds.2010-3189.

Veerkamp, R. F., and R. Thompson. 1999. A covariance function for feed intake, live weight, and milk yield estimated using a random regression model. J. Dairy Sci. 82:1565-1573. https://doi.org/10 .3168/jds.S0022-0302(99)75384-1.

Weißhuhn, P., M. Reckling, U. Stachow, and H. Wiggering. 2017. Supporting agricultural ecosystem services through the integration of perennial polycultures into crop rotations. Sustainability 9:2267. https://doi.org/10.3390/su9122267.

\section{ORCIDS}

Getinet Mekuriaw Tarekegn (ํ) https://orcid.org/0000-0001-7221-2473

Johanna Karlsson @ https://orcid.org/0000-0002-2987-8330

Cecilia Kronqvist @ https://orcid.org/0000-0003-3005-1004

Britt Berglund @ https://orcid.org/0000-0003-0927-7041

Kjell Holtenius @ \. https://orcid.org/0000-0003-1739-263X

Erling Strandberg ํㅜ https://orcid.org/0000-0001-5154-8146 